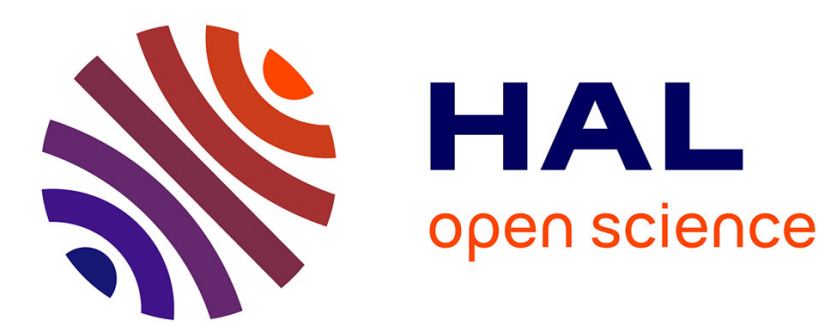

\title{
The heteromorph ammonite genus Ancyloceras (Ancyloceratidae) in the Paris Basin (lower Aptian, Lower Cretaceous, NE France)
}

Stéphane Bersac, Didier Bert

\section{- To cite this version:}

Stéphane Bersac, Didier Bert. The heteromorph ammonite genus Ancyloceras (Ancyloceratidae) in the Paris Basin (lower Aptian, Lower Cretaceous, NE France). Annales de Paléontologie, 2020, 106 (2), pp.102365. 10.1016/j.annpal.2019.102365 . insu-02360719

\section{HAL Id: insu-02360719 https://hal-insu.archives-ouvertes.fr/insu-02360719}

Submitted on 20 Nov 2019

HAL is a multi-disciplinary open access archive for the deposit and dissemination of scientific research documents, whether they are published or not. The documents may come from teaching and research institutions in France or abroad, or from public or private research centers.
L'archive ouverte pluridisciplinaire HAL, est destinée au dépôt et à la diffusion de documents scientifiques de niveau recherche, publiés ou non, émanant des établissements d'enseignement et de recherche français ou étrangers, des laboratoires publics ou privés. 


\section{Annales de Paléontologie}

\section{The heteromorph ammonite genus Ancyloceras (Ancyloceratidae) in the Paris Basin (lower Aptian, Lower Cretaceous, Northeast of France) \\ --Manuscript Draft--}

\begin{tabular}{|l|l|}
\hline Manuscript Number: & ANNPAL-D-19-00012 \\
\hline Article Type: & Article original \\
\hline Keywords: & $\begin{array}{l}\text { Ancyloceras; heteromorph ammonite; intraspecific variability; lower Aptian; Paris } \\
\text { Basin. }\end{array}$ \\
\hline Corresponding Author: & $\begin{array}{l}\text { Stéphane Bersac } \\
\text { GPAmmonites } \\
\text { La Mure-Argens, FRANCE }\end{array}$ \\
\hline First Author: & Stéphane Bersac \\
\hline Order of Authors: & Stéphane Bersac \\
\hline Abstract: & $\begin{array}{l}\text { Didier BERT, PhD } \\
\text { In the present work, we examine a sample of } 54 \text { specimens of the heteromorph } \\
\text { ammonite genus Ancyloceras d'Orbigny, 1842 from the Argiles à Plicatules Formation } \\
\text { (lower Aptian, Lower Cretaceous) of the eastern Paris Basin (NE France). The results } \\
\text { are as follows: (1) the sample is regarded as monospecific and assigned to the well- } \\
\text { named species Ancyloceras varians d'Orbigny, 1842; (2) its variability is continuous } \\
\text { and concerns as well as adult size, coiling and shell ornamentation. Adult size varies } \\
\text { by a factor of two from one individual to another. The angle between the proversum } \\
\text { and the retroversum is variable. The ornamentation on the spiral and the proversum } \\
\text { varies between robust morphotype with trituberculate strong ribs separated by few } \\
\text { smooth intercalaries ribs and slender morphotype with feebly tuberculate ribs. There } \\
\text { are no arguments in favor of sexual dimorphism in Ancyloceras varians. }\end{array}$ \\
\hline
\end{tabular}




\section{The heteromorph ammonite genus Ancyloceras (Ancyloceratidae) in the Paris Basin (lower Aptian, Lower Cretaceous, NE France)}

Le genre d'ammonite hétéromorphe Ancyloceras (Ancyloceratidae) dans le bassin parisien (Aptien inférieur, Crétacé inférieur, NE de la France)

Stéphane Bersac ${ }^{\mathrm{a}, *}$, Didier Bert ${ }^{\mathrm{a}, \mathrm{b}, \mathrm{c}}$

${ }^{\text {a }}$ Laboratoire du Groupe de recherche en paléobiologie et biostratigraphie des Ammonites, Bois-Mésanges, quartier Saint-Joseph, 04170 La Mure-Argens, France.

b Réserve naturelle nationale géologique de Haute-Provence, Conseil départemental des Alpes de HauteProvence, 13 rue du Docteur-Romieu, CS 70216, 04995 Digne-Les-Bains cedex 9, France.

c Laboratoire Géosciences, UMR-CNRS 6118, université de Rennes-1, campus Beaulieu, bâtiment 15, 35042 Rennes cedex, France.

* Corresponding author.

E-mail addresses: geosteber@yahoo.fr (S. Bersac), didier.paleo@gmail.com (D. Bert).

\section{ABSTRACT}


In the present work, we examine a sample of 54 specimens of the heteromorph ammonite genus Ancyloceras d'Orbigny, 1842 from the Argiles à Plicatules Formation (lower Aptian, Lower Cretaceous) of the eastern Paris Basin (NE de la France). The results are as follows: (1) the sample is regarded as monospecific and assigned to the well-named species Ancyloceras varians d'Orbigny, 1842; (2) its variability is continuous and concerns as well as adult size, coiling and shell ornamentation. Adult size varies by a factor of two from one individual to another. The angle between the proversum and the retroversum is variable. The ornamentation on the spiral and the proversum varies between robust morphotype with trituberculate strong ribs separated by few smooth intercalaries ribs and slender morphotype with feebly tuberculate ribs. There are no arguments in favor of sexual dimorphism in Ancyloceras varians.

\section{RÉSUMÉ}

Dans le présent travail, nous avons étudié un échantillon de 54 spécimens du genre d'ammonite hétéromorphe Ancyloceras d'Orbigny, 1842 des Argiles à Plicatules (Aptien inférieur, Crétacé inférieur) de l'est du bassin parisien (NE de la France). Les résultats sont les suivants: (1) l'échantillon est considéré comme monospécifique et attribué à l'espèce bien nommée Ancyloceras varians d'Orbigny, 1842; (2) sa variabilité est continue et concerne aussi bien la taille adulte, l'enroulement que l'ornementation de la coquille. La taille adulte varie d'un facteur 2 d'un individu à l'autre. L'angle formé par le proversum et le retroversum est variable. L'ornementation de la spire et du proversum varie entre un morphotype robuste à fortes côtes trituberculées séparées par des intercalaires atuberculées et un morphotype gracile 
à côtes faiblement tuberculées. Il n'y a pas d'argument en faveur d'un dimorphisme sexuel chez Ancyloceras varians.

Key words: Ancyloceras, heteromorph ammonite, intraspecific variability, lower Aptian, Paris Basin.

Mots clés: Ancyloceras, ammonite hétéromorphe, variabilité intraspécifique, Aptien inférieur, bassin parisien.

\section{Introduction}

D’Orbigny (1842, p. 491) introduced the genus Ancyloceras d'Orbigny, 1842 to name Jurassic and Lower Cretaceous planispiral heteromorph ammonites composed of a spiral and a hook. Thereafter, 'the name Ancyloceras was apt to be applied to any hooked-shaped heteromorph, whether of Jurassic or Cretaceous age' (Casey, 1960, p. 21). Nowadays, the genus Ancyloceras is generally restricted to lower Aptian (Lower Cretaceous) medium to large-sized heteromorph ammonites composed of a spiral, a proversum, a flexus and a retroversum (Kakabadze and Hoedemaeker, 2004 and see Fig. 1 for an illustration of the various parts of the Ancyloceras shell). Its ornamentation typically consists of trituberculate main ribs alternating with smooth intercalaries on the spiral and the proversum, and of strong ribs on the flexus and the retroversum. Ancyloceras is the type genus of the family Ancyloceratidae Gill, 1871 and its type species is Ancyloceras matheronianum d'Orbigny, 1842 (Haug, 1889). 
Ancyloceras is one of the most iconic ammonite genera of the Lower Cretaceous and it is frequently cited in the literature (Klein et al., 2007). Despite this, the evolutionary patterns and the intraspecific variability of the species nowadays assigned to the genus Ancyloceras remain little known, especially because no population study has ever been conducted. The objective of the present work is to conduct such a study on a sample of Ancyloceras from the Argiles à Plicatules, a lower Aptian formation of the north-east of France, by determining the taxonomic diversity of these Ancyloceras and the patterns of intraspecific variability of the recognized species.

\section{State of the art}

The Argiles à Plicatules are a lower Aptian plurimetric clayey formation of the eastern Paris Basin (NE France, Fig. 2). They are the type stratum of several 'classical' (i.e. frequently quoted in the literature) ammonite species such as Deshayesites deshayesi (d'Orbigny, 1841), Cheloniceras cornuelianum (d'Orbigny, 1841), Toxoceratoides royerianum (d'Orbigny, 1842), Pseudosaynella bicurvata (Michelin, 1838), etc. (see Bersac and Bert, 2015). No outcrop of the Argiles à Plicatules Formation is permanently accessible in good conditions since the early Twentieth Century. Therefore, most of the ammonites of this formation still available for review are specimens collected more than one century ago and currently deposited in various public institutions (Bersac and Bert, 2015, 2018). Unfortunately, the stratigraphic position of this material is not precisely known within the Argiles à Plicatules (see discussion in Bersac and Bert, 2015). This material is represented by three distinct taphopopulations: (1) one taphopopulation composed of relatively small pyritic ammonites assigned to the Deshayesites deshayesi Subzone (Deshayesites deshayesi Zone in the sense of 
Bersac et al. 2012, see Bersac and Bert, 2015); (2) one taphopopulation composed of larger hematized ammonites assigned to the $D$. deshayesi Subzone or to the base of the Deshayesites multicostatus Subzone (Bersac and Bert, 2018). It is likely that both these taphopopulations are contemporaneous and occur within the same level because they share the same host rock (compare Bersac and Bert, 2015, pl. 1, fig. 8, 9 and ibidem, pl. 2, fig. 1, pl. 3, fig. 4, 5) and because the inner whorls of the hematized ammonites are frequently pyritized (ibidem, plate 5, fig. 10); and (3) the last one is represented by phosphatized, pyritic or marly calcareous ammonites assigned to the Dufrenoyia furcata Zone (Amédro and Matrion, 2004; Bulot et al., 2018).

D’Orbigny (1842) introduced the species Ancyloceras varians d'Orbigny, 1842 on the basis of specimens from the Argiles à Plicatules Formation. This represents the first report of the genus Ancyloceras within this formation. Thereafter, d'Orbigny (1850) regarded A. varians as a junior synonym of Ancyloceras matheronianum. Busnardo (in Gauthier, 2006, p. 151) carried out a revision of $A$. varians. He designated a type specimen and noticed that $A$. varians is indeed morphologically similar to A. matheronianum. He also noticed that this species exhibits a wide intraspecific variability between robust specimens with thick trituberculate ribs on the proversum and slender specimens resembling Ancyloceras renauxianum d'Orbigny, 1842. Nevertheless, the morphological characteristics of A. varians from the Argiles à Plicatules remain little known, since only two fragmentary specimens have been figured (d'Orbigny, 1842, pl. 126, fig. 1-4; Busnardo in Gauthier, 2006, pl. 30, fig. 1a, b).

Three other species frequently assigned to the genus Ancyloceras have been reported from the Argiles à Plicatules Formation: Ancyloceras matheronianum, Ancyloceras renauxianum and Toxoceras cornuelianus d'Orbigny, 1842 (d'Orbigny, 1850; Cotteau, 1853; Lambert, 1916; Corroy, 1925; Stchépinsky, 1962). None of the specimens from this formation identified 
under A. matheronianum or A. renauxianum have been figured. D'Orbigny (1842) described under Toxoceras cornuelianus small spiral fragments. Thereafter, Toxoceras cornuelianus has generally been assigned to the genus Ancyloceras (d'Orbigny, 1850; Cotteau, 1853; Lambert, 1916; Stchépinsky, 1962). Busnardo (in Gauthier, 2006) also revised this species: he designated a lectotype and doubtfully assigned Toxoceras cornuelianus to the genus Ancyloceras. To our turn, we have also examined several specimens of $T$. cornuelianus from the Argiles à Plicatules Formation, including the type specimen of this species. In our opinion, this species is a probable primitive representative of the heteromorph ammonite genus Ammonitoceras Dumas, 1876 (work in progress).

As this is the case for the other ammonites of the Argiles à Plicatules, the stratigraphic position of these taxa is not precisely known within this formation: Péron (1905) simply mentioned a level with 'large uncoiled cephalopods' (translation from Péron, 1905, p. 377) and Lambert (1916) reported a level with 'large Ancyloceras' (translation from Lambert, 1916, p. 225) at the top of this formation, with no further details.

\section{Material, objectives and method}

\subsection{Material}

The studied material is composed of 'historical' specimens collected during the Nineteeth Century in the Argiles à Plicatules Formation and deposited in the following French public institutions: the Pierre et Marie Curie University (UPMC - Paris, ex Sorbonne's collection), the Natural History National Museum (MNHN - Paris) and the Municipal Museum of SaintDizier (Haute-Marne department). These collections contain numerous specimens (generally 
fragmentary) of heteromorph ammonites from the Argiles à Plicatules Formation. In a first step we selected all the specimens that may potentially be assigned to the genus Ancyloceras. Many of them are fragments of relatively small proversa that can belong to small Ancyloceras as well as to large representatives of the genus Toxoceratoides Spath, 1924 (Helicancylidae Hyatt, 1894 in the sense of Bert, 2009). Because these fragments cannot be reliably assigned to either of these two taxa, we excluded them from the study. The 54 remaining specimens include the lectotype of Ancyloceras varians and constitute the study sample. These specimens are most often fragments of spiral, proversum or retroversum. Their taphonomy is similar to those of the Deshayesites Kasansky, 1914 and Cheloniceras Hyatt, 1903 previously studied by Bersac and Bert $(2015,2018)$ : the specimens are preserved as pyritic or hematized internal casts. Two different taphopopulations are thus represented within the study sample: the taphopopulation of large hematized specimens and the taphopopulation of small pyritic ones (see Chapter 2 for a discussion of the various ammonite taphopopulations recognized in the Argiles à Plicatules Formation). Some of them are plaster casts of unfound original specimens (Fig. 3A1-A3, Fig. 4F1, F2). Only two specimens are subcomplete (Fig. 3A1-A3, Fig. 4F1, F2), and some have been 'restored' with plaster probably soon after being harvested (Fig. 3D2, Fig. 5E1, E2). Suture lines are sometimes well preserved. Each specimen was, or is still glued on a piece of cardboard on which the original formation and locality are generally handwritten (Fig. 3C1, C2). The original locality of 11 specimens cannot be determined because their piece of cardboard is lost or because it does not contain this information. The 43 other specimens come from 4 different localities of the eastern Paris Basin (Ancerville, Bailly-aux-Forges, Louvemont and Sommelonne, Fig. 2).

\subsection{Method}


The biostratigraphic framework follows Bersac et al. (2012, cf. Fig. 6), which is slightly modified from the standard Mediteranean-Caucasian Subrealm zonation proposed by Reboulet et al. (2018).

The measurements taken on specimens are illustrated Fig. 1. The null hypothesis H0 is 'the study sample is monospecific'. The alternative hypothesis $\mathrm{H} 1$ is 'the study sample is plurispecific'. The statistical analysis was performed using the version $2.17 \mathrm{~b}$ of the software PAST (Hammer et al., 2001). Five variables were measured:

H: whorl height of the middle part of the flexus.

W: whorl width of the middle part of the flexus.

R: ratio between intercalary smooth ribs and principal trituberculate ribs on the proversum.

Ds: diameter of the spiral.

L: total length of the shell.

The study is based on a relatively limited statistical analysis due to the fragmentary state of most of the specimens. In particular, the spiral parameters were not included in the statistical analysis since only 5 specimens have at least half a whorl of this part of the shell preserved (Fig. 3A1, H1, I1, J1 and Fig. 4F1). L was measured on the only two subcomplete specimens. Ds could be measured on only one of the two subcomplete specimens (SU.PAL.2019.0.290, Fig. 3A1-A3). Consequently, L and Ds were not included in the statistical analysis. As a consequence, only $\mathrm{H}, \mathrm{W}$ and $\mathrm{R}$ were included in the analysis, in addition with the ratio $\mathrm{W} / \mathrm{H}$. The ratio between the spiral diameter Ds and the total length of the shell L has been calculated for the specimen No. SU.PAL.2019.0.290 (Fig. 3A1-A3) only.

Specimens have been grouped in subsamples according to their original locality. Those for which original locality is unknown were excluded from the analysis. Therefore, only 19 
specimens were statistically studied. Univariate, bivariate and multivariate analyses have been performed according to the method described by Bersac and Bert (2015, p. 273, 274). With regard to the multivariate analysis, we have performed an Analysis Of Similarity (ANOSIM) only: the few analyzed variables and the relatively small size of the statistically studied sample render unnecessary a Principal Component Analysis (PCA) to be performed.

The suture line has not been quantitatively studied because of its little taxonomic significance at specific rank (Donovan et al., 1981; Wiedmann and Kulmann, 1981; Rouget, 2002).

\section{Results}

\subsection{Univariate and bivariate analyses}

The results of the univariate analysis are given in Table 1 . The total length $\mathrm{L}$ of the two subcomplete specimens is respectively 149.8 and 224 mm (respectively Fig. 4F1, F2 and Fig. 3A1-A3). The value of Ds is $50.6 \mathrm{~mm}$ and the ratio between Ds and $\mathrm{L}$ is $22.6 \%$ for the specimen No. SU.PAL.2019.0.290 (Fig. 3A1-A3).

The results of the bivariate analysis are given in Fig. 7 and Fig. 8. Only $\mathrm{H}$ and $\mathrm{W}$ are linked by isometric function and are thus regarded as 'dependent' variables (see Bersac and Bert, 2015 for explanation). Conversely, $\mathrm{H}$ (or $\mathrm{W}), \mathrm{R}$ and $\mathrm{W} / \mathrm{H}$ are 'independent' variables. The distributions of $\mathrm{H}$ and $\mathrm{W}$ are unimodal and do not depart significantly from normality (Fig. 8 and Fig. 9). The distribution of $\mathrm{R}$ exhibits a main mode and a small pick. It is strongly positively skewed and it departs from normality (Fig. 8 and Fig. 9). The main mode has a value around 1.5 and the small pick, determined by only two specimens, has a value around 7. This indicates that the value of $\mathrm{R}$ is relatively low most of the case, but it is never less than 
one: most of the specimens have one or a little bit more than one intercalary rib between two main trituberculate ribs on average. The five specimens with a value of $\mathrm{R}$ over 3 (i.e. the more slender specimens) all belong to the Louvemont subsample (Fig. 8). The type specimen of $A$. varians has one of the highest values of $\mathrm{H}$ and $\mathrm{W}$ (Fig. 9).

\subsection{ANOSIM}

The 19 quantitatively studied specimens were included in the ANOSIM. The ANOSIM did not find any statistically significant difference between subsamples $(p=0.142)$ and no pairwise comparison was thus performed.

\section{Interpretation and discussion}

\subsection{Homogeneity of the study sample}

The results of the statistical analysis allow us to consider the study sample as homogeneous for the following reasons: (1) the distributions of $\mathrm{H}$ and $\mathrm{W}$ are unimodal and do not depart from normality; and (2) the distribution of R is considered 'more or less' unimodal because the small pick for the high values of $\mathrm{R}$ is not considered to be significant as it is only determined by two specimens.

The specimens discarded from the statistical analysis are fragments of proversum and spiral that share the same shape, ornamentation and morphological variability with the proversa of the 19 specimens of the quantitative analysis. The fragments of proversum seem to 
continuously vary between slender morphotype with feebly tuberculate ribbing (compare Fig. 5E1, E2 and Fig. 5F1, F2) and robust morphotype with thick trituberculate ribs (compare Fig. 3C1, C2 and Fig. 4E1, E2). This is the same with spirals, which are represented by a slender morphotype (compare for example Fig. 3J1, J2 and Fig. 4F1, F2) and a more robust morphotype (compare for example Fig. 3A1, A2 and Fig. 3L) linked by all intermediates. Note that the type specimen of A. varians (Fig. 5A1-A4) is a particularly large and robust specimen. The patterns of intraspecific variability of the study sample are illustrated Fig. 10.

\subsection{Adult size variation}

The adult size of the shell is quantified by L (total length of the shell). When L is unknown, it can be estimated with $\mathrm{H}$ (whorl height of the middle part of the flexus): in heteromorph tripartite ammonite species, both variables are relatively correlated (Delanoy, 1997; Ropolo et al., 1999). In our studied sample, $H$ continuously varies by a factor of two (Table 1) and one can thus estimate that the adult size of the specimens varies in the same way. Because it is continuous, this variability cannot be attributed to a sexual dimorphism. Such a large variability is relatively frequent among ammonites (see De Baets et al., 2015, p. 389) and was occasionally described among tripartite heteromorph taxa (Heteroceras emerici d'Orbigny, 1842, Heteroceratidae Spath, 1922 in Delanoy, 1997, table 6, Scaphites whitfieldi Cobban, 1951, Scaphitidae, Gill, 1871 in Landman, 1987, fig. 77). Among the Ancyloceratidae, the few described cases show a less significant adult size variation: the adult size (named ' $H=$ total height of the shell ${ }^{6}$ in Ropolo et al., 1999, p. 168) of the several species of Pseudocrioceras Spath, 1924 described by Ropolo et al. (1999) varies by a factor of 1.42 to 1.58 from a species to another. For the typical forms and the three varieties of Proautraliceras 
gigas (J. de C. Sowerby, 1840) described and figured by Casey (1961a, = Australiceras gigas in Casey, 1960), this variability has a factor of 1.39 [the varietal names proposed by Casey (1961a) for this species were thereafter considered superfluous by Casey et al. (1998)].

\subsection{Ornamental variation}

$\mathrm{R}$ (ratio between intercalary smooth ribs and principal trituberculate ribs on the proversum) continuously varies by a factor of 8 in our sample. $\mathrm{R}$ is an indicator of robustness of the ornamentation: when $\mathrm{R}$ is at low value, the main trituberculate ribs are less spaced, which gives a more robust appearance to the ornamentation. It is to note that there is no correlation between $\mathrm{R}, \mathrm{H}$ and $\mathrm{W}$ : considering that $\mathrm{H}$ is an indicator of the adult size, there is no evidence of correlation between adult size and robustness of the ornamentation. In other words, small specimens are not especially more slender or more robust than larger specimens. Intraspecific variability of ornamentation among Ancyloceratidae has received little attention in the literature. Nevertheless, Roch (1927) and Casey (1961a) have noticed a certain degree of variation in the ribbing density of A. matheronianum from southeastern France and Proaustraliceras gigas from southern England. The population studies carried out on other families of Cretaceous heteromorph ammonites always conclude to a large intraspecific ornamental variability (Landman, 1987; Ropolo, 1995; Kin, 2010; Bert, 2014a, 2014b; Hoffmann et al., 2019; Matamales-Andreu and Company, 2019).

\subsection{Coiling variation}


In our study sample, there is a slight variation of the coiling of the retroversum. This latter forms a more or less open angle with the proversum, varying from specimen to specimen (compare for example Fig. 4B1 with Fig. 4C1). Such a coiling variability has already been figured by Roch (1927, fig. I to VI, p. 24) in A. matheronianum.

\subsection{Biostratigraphic position of the study sample}

The large hematized fragments of Ancyloceras from Ancerville, Bailly-aux-Forges, Louvemont and Sommelonne belong to the taphopopulation of the large hematized specimens, which can thus be assigned to the $D$. deshayesi Subzone or the basal $D$. multicostatus Subzone (Fig. 6 and see discussion about the various ammonite taphopopulations recognized in the Argiles à Plicatules and their biostratigraphic assignment in chapters 2 and 3.1). The small pyritic fragments of spiral and proversum from Bailly-auxForges (Fig. 3H1, H2, J1, J2) belong to the same taphopopulation as the 127 pyritic Deshayesites studied by Bersac and Bert (2015), which are assigned to the D. deshayesi Subzone of the D. deshayesi Zone (Fig. 6).

Two assumptions can thus be proposed concerning the biostratigraphic assignment of the study sample: 1) considering that the hematized Ancyloceras (taphopopulation of the large hematized ammonites, assigned to the D. deshayesi Subzone or the basal D. multicostatus Subzone, see chapters 2 and 3.1) and the pyritic Ancyloceras (taphopopulation of the small pyritic ammonites assigned to the $D$. deshayesi Subzone) occur within different levels, the study sample has to be assigned to the $D$. deshayesi Subzone and maybe the basal $D$. multicostatus Subzone; 2) Considering that the hematized Ancyloceras and the pyritic Ancyloceras occur within the same levels (i.e. considering that the taphopopulation of small 
pyritic ammonites and the taphopopulation of large hematized ones occur within the same level), the study sample has to be assigned to the D. deshayesi Subzone. In both assumptions, the biostratigraphic interval is relatively constrained.

\subsection{Monospecificity and taxonomic attribution of the study sample}

As far as possible, ammonite populations have to be studied from a restricted stratigraphic interval in order to avoid time-averaging (see discussion in de Baets et al., 2015, p. 363). Because the study sample is considered homogeneous (with continuous morphological variability) and because it is biostratigraphically constrained, no evidence can reject the null hypothesis H0: the study sample is regarded as monospecific.

Since the study sample is considered monospecific and includes the type specimen of $A$. varians, two taxonomic options have to be envisaged: 1) the study sample has to be attributed to the species $A$. varians or; 2) the study sample has to be attributed to another species regarded as a senior synonym of $A$. varians. A potential senior synonym of $A$. varians would have been published earlier [principle of priority, International Code of Zoological Nomenclature (ICZN) article 23] or simultaneously (principle of the first reviser, ICZN article 24) than this species.

Only one species potentially attributed to Ancyloceras has been published earlier than $A$. varians: Ancyloceras? humboldtianum (Lea, 1841). This species is based on a small fragment of heteromorph ammonite assigned to the Lower Jurassic ('lower series of the Oolitic group' in Lea, 1841, p. 253) of the province of Vélez (Colombia). In our opinion, this specimen (Lea, 1941, pl. VIII, fig. 1) is too fragmentary to deserve a generic status and we consider this species as a nomen dubium. The identification of the two additional specimens that were 
thereafter assigned to this species is thus doubtful (Forbes, 1845, text-fig. A, b on page 175; Klinger and Kennedy, 1977, p. 221, fig. 2). In consequence, we do not consider A. varians as a subjective synonym of $A . ?$ humboldtianum.

Three species frequently assigned to Ancyloceras were published simultaneously with $A$. varians: A.? cornuelianum (d'Orbigny, 1842) (=Toxoceras cornuelianus in d'Orbigny, 1842, p. 484), A. matheronianum d'Orbigny, 1842 and A. renauxianum d'Orbigny, 1842. As already exposed in Chapter 2, A.? cornuelianum is probably a primitive representative of the genus Ammonitoceras and it cannot be regarded as a junior synonym of $A$. varians.

Ancyloceras matheronianum was introduced to characterize large ancyloceratic ammonites from Cassis-la Bédoule and Barrême (SE France; adult size L=430 $\mathrm{mm}$ according to d'Orbigny, 1842, p. 497, pl. 122, fig. 1) that bear an alternation of trituberculate and atuberculate ribs on the spiral, the proversum and the young part of the flexus. As previously mentioned, A. matheronianum is the type species of the genus Ancyloceras and d'Orbigny (1850) thereafter considered $A$. varians as a subjective synonym of A. matheronianum. Busnardo (in Gauthier, 2006, p. 147, pl. 29, fig. 1) designated a lectotype from the lower Aptian of Cassis-la-Bédoule. The range of intraspecific variability and the precise biostratigraphic position of $A$. matheronianum are not known, despite the fact that this species is frequently quoted in the literature (Klein et al., 2007). This species seems to differ from $A$. varians by an adult size twice as large (d'Orbigny, 1842; Busnardo in Gauthier, 2006). In our opinion, biostratigraphic and intraspecific variability-related data are insufficient to determine if $A$. matheronianum and A. varians may or may not be synonymized.

Ancyloceras renauxianum was introduced for very large ancyloceratic forms with tubercleless spiral and proversum (adult size around $\mathrm{L}=550 \mathrm{~mm}$ according to d'Orbigny, 1842, p. 499, pl. 123, fig. 1) from the Aptian of SE France (Cassis-la Bédoule, Apt and the Var 
department). Because of the slender ornamentation d'Orbigny depicted on the spiral part and the proversum, this taxon is frequently assigned to the upper Barremian genus Audouliceras Thomel, 1964 (Klein et al., 2007); it has later became the type species of the genus Gonneticeras Vermeulen and Lazarin, 2007 (Vermeulen and Lazarin, 2007). More recently, Busnardo (in Gauthier, 2006, p. 148, pl. 26, fig. 1) designated a lectotype originating from an unknown level of the Aptian of Cassis-la Bédoule. This lectotype differs from A. varians by its significantly larger adult size and may correspond to a slender form of A. matheronianum. As with A. matheronianum, too little biostratigraphic and intraspecific variability-related data are known concerning A. renauxianum to determine if this species may or may not be synonymized with $A$. varians.

In consequence, we consider that no species related to Ancyloceras and published before of simultaneously with A. varians can be regarded as a senior synonym of A. varians. For theses reasons, and because it is considered monospecific and because it includes the type specimen of $A$. varians, the study sample is attributed to the species A. varians.

\section{Systematics}

Order Ammonoidea Zittel, 1884

Suborder Ancyloceratina Wiedmann, 1966

Family Ancyloceratidae Gill, 1871

Genus Ancyloceras d'Orbigny, 1842

Ancyloceras varians d'Orbigny, 1842

Figs. 3, 4 and 5

1842 Ancyloceras varians sp. nov. - d'Orbigny, p. 504, pl. 126, fig. 1, 2, 3, 4. 
? 1881 Crioceras urbani sp. nov. - Neumayr and Uhlig, p. 62, pl. XLIX, fig. 3a, b, pl. L, fig. 1.

1850 Ancyloceras varians d'Orb. - d'Orbigny, p. 114.

? 1853 Ancyloceras Matheronianus d'Orb. - Cotteau, p. 15.

1913 Ancyl. varians d'Orb. - Kilian, p. 351.

? $\quad 1913$ Crioceras Tabarelli Ast. - Kilian, p. 315, 351

1915 Ancyl. varians d'Orb. - Kilian and Reboul, p. 67, 68.

? 1916 Ancyloceras cf. Matheroni-Lambert, p. 225.

? 1916 Ancyloceras Renauxi-Lambert, p. 225.

1925 Ancyloceras varians d'Orbigny - Corroy, 1925, p. 270.

? 1925 Ancyloceras Matheronianum d'Orbigny-Corroy, 1925, p. 270.

? 1925 Ancyloceras Renauxianum d'Orbigny - Corroy, 1925, p. 270.

1925 Grioceras Tabarelli Ast. - Corroy, 1925, p. 270.

? $1930 \quad$ Ancyloceras aff. varians d'Orbigny, 1842 - Spath, p. 454

? 1960 Ancyloceras cf. varians d'Orbigny, 1842 - Casey, p. 23, pl. II, fig. 2a, b (= Spath, 1930, p. 454).

? 1962 Ancyloceras Matheronianum d'Orb. - Stchépinsky, p. 87.

Non 1962 Ancyloceras sp. aff. varians d'Orb. - Collignon, p. 14, fig. 961.

? 1971 Protanisoceras raulianum - Kemper, pl. 25, fig. 2.

? 1976 Ancyloceras varians d'Orb. - Kemper, pl. 25, fig. 2 (=Kemper, 1971, pl. 25, fig. 2).

? 1995 Ancyloceras varians d'Orb. - Kemper, pl. 5, fig. 3 (=Kemper, 1971, pl. 25, fig. 2). 
2006 Ancyloceras varians d'Orbigny, 1842 - Busnardo (in Gauthier), p. 150, pl. 30, fig. 1a, b.

? 2010 Ancyloceras urbani (Neumayr and Uhlig, 1883) - Malkoč et al., fig. 7E, F.

? 2012 Ancyloceras varians (d'Orbigny, 1842) - Lehmann et al., 2012, p. 42, text.fig. 7, fig. 5a, b.

? 2012 Audouliceras urbani (Neumayr and Uhlig, 1881) - Lehmann et al., 2012, p. 42, text.fig. 7 , fig. $1 \mathrm{c}$.

Lectotype: specimen No. MNHN.F.R00847 designated by Busnardo (in Gauthier, 2006 p. 150, pl. 30, fig. 1a, b and figured here Fig. 5A1-A4), curated in the Natural History National Museum of Paris (France). This specimen is one of the 4 syntypes grouped under the No. 5605E of the d'Orbigny's collection. The specimens No. MNHN.F.A57402, MNHN.F.A71271 and MNHN.F.A71272 (formerly 3 of the 6 syntypes grouped under the No. 5605E) are paralectotypes (figured here respectively Fig. 5B1, B2, C1, C2, D1 and D2).

Remark about the status of the type-specimen of $\boldsymbol{A}$. varians: d'Orbigny (1842, p. 504) did not designate any type specimen when he introduced the species Ancyloceras varians. In the original description, he pointed out that 'this species has been discovered by Mr Royer and Mr Cornuel in Bailly-aux-Forges and Narcy (Haute-Marne), in the Argiles à Plicatules' (translation from d'Orbigny, 1842, p. 506) and that the 4 original figurations (d'Orbigny, 1842, pl. 126, fig. 1-4) represent a ' fragment with hook, drawn in its natural size and based on samples from Royer's and Cornuel's collections' (translation from d'Orbigny, 1842, p. 506). These original figurations are thus synthetographs. Thereafter, d'Orbigny (1850, p. 114, $\left.\mathrm{n}^{\circ} 41\right)$, in his Prodrome de Paléontologie Stratigraphique Universelle des 
Animaux Mollusques et Rayonnés, considered A. varians as a junior synonym of Ancyloceras matheronianus. The d'Orbigny's collection was subsequently sold to the Natural History National Museum of Paris in 1858 (one year after d'Orbigny passed away; Lauriat-Rage, 2002) and a catalogue of the collection was established by Mr Hippolyte Hupé during the period 1858-1860 (Lauriat-Rage, 2002; Gauthier and Fischer in Gauthier, 2006, p. 8). In this catalogue, Hupé applied the taxonomic positions of d'Orbigny's Prodrome (1850) and provided information about the synonymies of the specimens (Gauthier and Fischer in Gauthier, 2006).

According to the Hupé's catalogue, the d'Orbigny's collection contains 6 specimens identified under Ancyloceras matheronianus that were originally identified under Ancyloceras varians by d'Orbigny himself. Hupé grouped them under the same number 5605E. These specimens are the only known identified under A. varians by d'Orbigny himself. They all come from Ancerville (Meuse department, France, Fig. 2), a locality not mentioned by d'Orbigny (1842) in his original description of A. varians (Busnardo in Gauthier, 2006, p. 150). Only 4 of these specimens are still present in the d'Orbigny's collection (Busnardo in Gauthier, 2006). They are shown in Fig. 5A1-A4, B1, B2, C1, C2, D1 and D2. Busnardo (in Gauthier, 2006) designated the lectotype of A. varians among them (Busnardo in Gauthier, 2006, p. 150). This specimen was thereafter numbered MNHN.F.R00847.

Although the original locality of the lectotype designated by Busnardo (in Gauthier, 2006) is not quoted in the original description of $A$. varians, we consider here this designation valid because it respects the rules of the ICZN for the following reasons:

- The Hupé's catalogue demonstrates that the 4 remaining specimens of the d'Orbigny's collection grouped under the No. 5605E were originally identified under A. varians by d'Orbigny himslef. We thus suggest that these specimens have to be considered as 
representatives of the type series of $A$. varians and thus as syntypes (ICZN articles 72.1.1 and 73.2).

- There is no rule in the ICZN that allows excluding specimens of a type series of a given species under the pretext that they come from a locality not quoted in the original description of this species (see ICZN articles 76.1 and 76.2).

- The lectotype of $A$. varians has to be designated among the 4 syntypes (ICZN articles 74.1 and 75.1), and this is what Busnardo (in Gauthier, 2006) did.

- Busnardo (in Gauthier, 2006) called 'lectotype' this specimen at least one time. This implies that the 3 other syntypes (No. MNHN.F.A57402, MNHN.F.A71271, MNHN.F.A71272, Fig. 5B1, B2, C1, C2, D1 and D2) are paralectotypes of $A$. varians (ICZN article 74.1.2).

Type-locality: Ancerville (Meuse department, NE France).

Type stratum: the Argiles à Plicatules Formation.

Biostratigraphic distribution: lower Aptian, Deshayesites deshayesi Subzone and maybe basal Deshayesites multicostatus Subzone of the Deshayesites deshayesi Zone.

Diagnosis: medium-sized species of Ancyloceras with an important intraspecific variability, ranging from subatuberculate forms to forms with robust trituberculate ribs separated by a single atuberculated rib on the spiral and the proversum. Adult size probably varying by a factor of two between individuals. No element for a sexual dimorphism. 
Description: medium-sized tripartite heteromorph ammonite with ancyloceratic coiling. Significant adult size variation (variation by a factor of 2). No evidence for sexual dimorphism. Shell consisting of a spiral, a proversum, a flexus and a retroversum (Fig. 1). Whorl section subcircular to suboval wider than high. Spiral diameter is $22.6 \%$ of the total length of the shell for the single specimen where this ratio could have been calculated (No. SU.PAL.2019.0.290, Fig. 3A1-A3). The spiral whorls are not in contact or just advolute. The proversum is straight or slightly curved with a ventral concavity, and its angle with the retroversum is variable. The ornamentation is highly variable with all the intermediate possible between slender and robust extreme morphotypes. This ornamentation is generally represented by strong trituberculate main ribs separated by 1-7 thin and tight atuberculate secondary ribs on the spiral, the proversum and the young part of the flexus. All the ribs are straight, radial or forwards and attenuated on the siphonal area. From the late part of the proversum, the main trituberculate ribs strengthen and the intercalary ribs decrease in number. The ventrolateral tubercle is generally larger than the lateral and ventrolateral ones. The retroversum have spaced, straight and thinner trituberculate ribs. Tubercles of the retroversum become smaller and smaller as they approach the peristome. The peristome is known on a single specimen (No. SU.PAL.2019.0.291, Fig. 3D1): it is slightly orally concave on the flanks, with a peak on the venter. On the spiral part and the proversum, the slender specimens have more atuberculate ribs and thinner trituberculate ribs than robust ones. On extreme slender morphologies, main ribs can only bear a single ventrolateral tubercle (No. SU.PAL.2019.0.289.1, Fig. 5F1, F2) or can even be totally absent on a portion of the proversum (No. SU.PAL.2017.0.47, Fig. 5E1, E2). The ornamentation on the dorsal area of the whole shell is represented by dense and thin ribs, which are curved with an oral concavity. 
Suture line of ancyloceratic type, with bifid saddles and trifid lateral and dorsal lobes, the second lateral lobe being smaller than the dorsal lobe.

Discussion: In the literature, only a few figured specimens were identified under A. varians. All of them are very fragmentary (Casey, 1960, pl. II, fig. 2a, b; Collignon, 1962, pl. 221, fig. 961; Kemper, 1976, pl. 25, fig. 2, Lehmann et al., 2012, text-fig. 7). Their biostratigraphic assignation varies from a specimen to another: Busnardo (in Gauthier, 2006, p. 151) assigned the type material of A. varians to the 'Bowerbanki Zone' (=Dufrenoyia furcata Zone), on the basis of the co-occurrence of Deshayesites dehayesi and A. varians within the Argiles à Plicatules (sic). Casey (1960, p. 23) assigned to the basal Aptian a small fragment from southern England (already quoted by Spath, 1930). Lehmann et al. (2012) assigned their German specimens to the basal Aptian Deshayesites fissicostatus Zone. Kemper (1976) figured a German specimen from the lower Aptian Deshayesites tenuicostatus Zone (equivalent to the Deshayesites weissi Zone of the Tethyan realm according to Malkoč et al., 2010, which corresponds nowadays to the Deshayesites forbesi Zone in the sense of Reboulet et al., 2018, see Reboulet et al., 2011). The upper Aptian Madagascan specimen figured by Collignon (1962, pl. 221, fig. 961) has recently been identified under Klingerites haughtoni (Klinger and Kennedy, 1977) by Bulot et al. (2018, p. 7, =?Toxoceratoides haughtoni in Klinger and Kennedy, 1977).

Corroy (1925, p. 270) quoted a specimen identified under 'Grioceras Tabarelli Ast.' from the Argiles à Plicatules Formation. This name refers to the species Ancyloceras tabarelli Astier, 1851, which has frequently been attributed to the genus Crioceras in old literature (e.g. Uhlig, 1883). The name 'Grioceras' is probably a spelling mistake. Ancyloceras tabarelli is nowadays attributed to the genus Acrioceras Hyatt, 1900 and is considered to be of early 
Barremian age (Thomel et al., 1990). The quotation of this species within the Argiles à Plicatules Formation by Corroy (1925) is probably linked to the fragment of spire No. SU.PAL.2019.0.292 (Fig. 3E): the same spelling mistake ('Grioceras') seems to be present on the piece of cardboard on which this specimen is glued. This specimen, which is from the locality of Sommelonne, is deposited in the Sorbonne's collection (nowadays part of the UPMC); it is also probably at the origin of the "Crioceras Tabarelli Ast." quotation within the Argiles à Plicatules by Kilian (1913, p. 315, 351, footnote).

The fact that many species of Ancyloceratidae were recognized within the Argiles à Plicatules Formation is probably caused by the significant intraspecific variability of $A$. varians (see Chapter 2). The quotation of $A$. renauxianum within this formation (Lambert, 1916, p. 225; Corroy, 1925, p. 270) is probably due to the fact that the slender morphology of A. varians resembles this species (as Busnardo in Gauthier, 2006 noticed himself). On the other hand, the frequent quotation of A. matheronianum (Cotteau 1853, p. 15; Lambert, 1916, p. 225; Corroy, 1925, p. 270; Stchepinsky, 1962, p. 87) is probably related to the fact that A. varians was rapidly synonymized with this species by d'Orbigny (1850) himself.

Affinities and differences: Some incomplete specimens with only the end of the proversum, the flexus and the retroversum, are very similar to some representatives of the heteromorph genus Lithancylus Casey, 1960 (Ancyloceratidae, compare Fig. 4E1, E2 and Mikhailova and Baraboshkin, 2001, pl. 5, fig. 2a, 2b). The question is: could these specimens be representatives of Lithancylus instead of A. varians ? The genus Lithancylus could theoretically occur within the Argiles à Plicatules Formation because it is reported from the D. annelidus Subzone of southern England (Fig. 6, Casey, 1960; Casey et al., 1998). Despite 
of this, in the collections we visited, we did not find any specimen from the Argiles à Plicatules than can be identified for sure as a Lithancylus. Furthermore, there is no figuration or quotation of this genus (or species nowadays assigned to this genus) in this formation in the literature. Because these fragmentary specimens are incomplete and can be identified as Ancyloceras as well as Lithancylus and because there is so far no evidence of the occurrence of Lithancylus within the Argiles à Plicatules, until proven otherwise we choose the most parsimonious hypothesis of considering these specimens as representatives of A. varians.

Ancyloceras mantelli Casey, 1960 is only known by its holotype (Casey, 1960; southern England). This specimen is assigned to the Deshayesites kiliani Subzone (Casey, 1960) of the D. forbesi Zone (in the sense of Casey et al., 1998). It differs from A. varians by slightly thicker ribs on the retroversum. The rest of its characteristics (adult size, ornamentation of the spiral, proversum and flexus) falls within the range of intraspecific variability of $A$. varians. Nevertheless, because no population study of A. mantelli has been conducted so far and because these taxa are not contemporaneous, we consider that additional data are required to determine if A. mantelli and A. varians may or may not be synonymous.

Crioceras urbani Neumayr and Uhlig, 1881 was described on the basis of specimens from the 'gray-green ferruginous levels from the Marie quarry near Steinlah' (lower Aptian, Salzgitter, Germany, translation from Neumayr and Uhlig, 1881, p. 63). This species was thereafter rapidly assigned to the genus Ancyloceras (von Koenen, 1902) because of its similarities with A. matheronianum and A. varians [as Neumayr and Uhlig (1881, p. 63) already noticed themselves]. On the basis of the original figurations (Neumayr and Uhlig, 1881, pl. XLIX, fig. 3a, b and pl. L, fig. 1), our opinion is that A. urbani falls into the intraspecific variability of $A$. varians. The type stratum of Ancyloceras urbani is also the type stratum of Deshayesites weissi (Neumayr and Uhlig, 1881) and Deshayesites latilobatus 
(Sinzow, 1910). It has provided small Deshayesites attributed to D. deshayesi by Neumayr and Uhlig (1881, p. 50) because, as for the D. deshayesi of the Paris Basin, the inner whorls of these specimens show a smooth siphonal band. A. urbani and $A$. varians have in addition a close biostratigraphic position and are in consequence probably conspecific.

Sarkar (1955) introduced the name Ancyloceras rochi Sarkar, 1955 (non Ancyloceras rochi Dimitrova, 1967) for a small Ancyloceras figured by Roch (1927, pl. IV, fig. 2) under Ancyloceras binelli. This specimen originates from an undetermined level of the lower Aptian of Cassis-la Bédoule (Roch, 1927, p. 29) and is similar to the small specimens of Ancyloceras Ropolo et al. (1998) collected in the Cassis-La Bédoule area and quoted as 'Ancyloceras matheroni d'ORBIGNY (small forms)' (translation from Ropolo et al., 1998, p. 171). These specimens are $150-170 \mathrm{~mm}$ in total length of the shell and are very close to the type specimen of A. rochi Sarkar, 1955 (Ropolo, personal communication, February 2018). Those specimens originate from levels earlier than the First Occurence Datum (FOD) of the Roloboceratinae in this area (Ropolo et al., 1998). The biostratigraphic position of the Roloboceratinae in the Cassis-La Bédoule area is under debate (Ropolo et al., 2008; Moreno-Bedmar et al., 2009) but in southern England, these latter occur from the lower part of the $D$. forbesi Zone (in the $D$. kiliani Subzone and doubtfully at the top of the D. fittoni Subzone, see Casey, 1961b; Casey et al., 1998; Bersac and Bert, 2015). If one considers that (1) the FOD of the Roloboceratinae is synchronous in southern England and in the Cassis-La Bédoule area and (2) the Ropolo et al.'s (1998) small Ancyloceras are indeed A. rochi Sarkar, 1955, then A. rochi Sarkar, 1955 would have an ornamentation similar to A. varians but would be smaller and older.

Ancyloceras rochi Dimitrova, 1967 non Ancyloceras rochi Sarkar, 1955 is a very large ancyloceratic species (size of the holotype around $\mathrm{L}=580 \mathrm{~mm}$ ) with a tubercle-less spiral and proversum. Its holotype originates from the lower Aptian of Gorsko Ablanovo, Bulgaria 
(Dimitrova, 1967, p. 57 and 218). Dimitrova (1967, p. 57, 58, 218 and 219) considers this specimen to be close to the specimen figured under Ancyloceras renauxianum by Roch (1927, pl. IV, fig. 1) despite the fact that this latter is twice as small. The ornamentation of $A$. rochi Dimitrova, 1967 is similar to that of the slender forms of $A$. varians but its adult size is significantly larger.

?Ancyloceras durelli Anderson, 1938 is a probable upper Barremian taxon only known in northern California by fragments of proversum and retroversum (Anderson, 1938; Murphy, 1975). ?Ancyloceras attrox Anderson, 1938 was described on the basis of a single fragmentary specimen from northern California and was assigned to the uppermost Barremian or to the basal Aptian (Anderson, 1938; Murphy, 1975). It was considered as a probable Lithancylus by Obata and Ogawa (1976) and as a Lithancylus by Toshimitsu and Hirano (2000). Assuming that they are representatives of the genus Ancyloceras, both Californian species differs from A. varians by their lower biostratigraphic occurrence and by a probably larger adult size.

Affinities and differences with A. matheronianum and A. renauxianum were discussed in Chapter 5.6.

\section{Conclusion}

In the present work, we have studied a sample of 54 Ancyloceras specimens from the Argiles à Plicatules Formation (lower Aptian of the Paris Basin), including the lectotype of $A$. varians. We initially faced two difficulties: (1) the studied material is from 'historical' collections and has not been bed-by-bed sampled and (2) most of the studied specimens are fragmentary. 
We nevertheless have chosen to study of this material because (1) the taphonomic characteristics of the specimens and the co-occurring species allow to estimate their biostratigraphic position (D. deshayesi Subzone and probably basal D. multicostatus Subzone of the D. deshayesi Zone); (2) the various studied fragments share homologous shell portions and; (3) the studied material allows to figure for the first time subcomplete specimens of Ancyloceras from the Argiles à Plicatules. The fragments composed of a proversum, a flexus and a retroversum were quantitatively and qualitatively studied and the fragments composed of a spiral or a proversum were only studied qualitatively. The results of these analyses could not invalidate our null hypothesis H0 stating that the study sample is monospecific. We thus consider our study sample as being represented by a single species: A. varians. We interpret this species as having a significant intraspecific variability. This latter concerns (1) the adult size (i.e. the total length of the shell), which varies by a factor of two; (2) the ornamentation, which varies between a sub-tuberculate slender morphotype and a robust morphotype with strong trituberculate ribs on the spiral and the proversum; and (3) the angle between the proversum and the retroversum that can be more or less open. This disparity seems not to be involved by sexual dimorphism.

\section{Acknowledgements}

We thank Pierre Ropolo for providing us data about the Ancyloceras of Cassis-La Bédoule. Bertrand Matrion and Philippe Courville are acknowledged for providing us data about the Argiles à Plicatules Formation. We express our gratitude to Isabelle Rouget, Nathalie Sauzières, Sylvain Charbonnier, Didier Merle, Jean-Michel Pacaud (Natural History National

Museum, Paris, France), Stéphane Jouve (Pierre et Marie Curie University, Paris, France), 
Cécile Varéon and Stéphane Lahierre (Municipal Museum, Saint-Dizier, France) for their welcome and their help, and for having widely facilitated us the access to the collections under their care. Pascal Neige (Université de Bourgogne, Dijon, France) and one anonymous reviewer are gratefully acknowledged for their constructive comments, which improved the manuscript.

\section{Disclosure of interest}

The authors declare that they have no competing interest.

\section{References}

Amédro, F., Matrion, B., 2004. Les ammonites aptiennes des Argiles à Plicatules de la bordure orientale du bassin de Paris: un aperçu. Bulletin de l'Association Géologique Auboise $24-25,75-80$.

Anderson, F. M., 1938. Lower Cretaceous deposits in California and Oregon. Geological Society of America Special Papers 16, x + 340 p.

Bersac, S., Bert, D., 2015. Two ammonite species under the same name: revision of Deshayesites deshayesi (d'Orbigny, 1841) based on topotype material (Lower Aptian, Lower Cretaceous, Northeast of France). Annales de Paléontologie 101(4), 265-294. 
Bersac, S., Bert, D., 2018. Revision of the lower Aptian (Lower Cretaceous) ammonite species Cheloniceras cornuelianum (d'Orbigny, 1841). Annales de Paléontologie 104(1), 4570.

Bersac, S., Bert, D., Matrion, B., 2012. Revision of the index-species Deshayesites deshayesi (Ammonoidea, Lower Aptian, Lower Cretaceous): taxonomic and biostratigraphic consequences. In: Bert, D., Bersac, S. (Eds.), First meeting of the Research Group for Paleobiology and biostratigraphy of the ammonites. Boletin del Instituto de Fisiografia y Geologia 82, p. 31-33.

Bert, D. (2009). Description de Artareites landii nov. (Ammonoidea) du Barrémien supérieur de Majastre (Sud-Est de la France) et discussion sur les Helicancylidae Hyatt, 1894. Annales de Paléontologie 95(3), 139-163.

Bert, D., 2014a. Factors of intraspecific variability in ammonites, the example of Gassendiceras alpinum (d'Orbigny, 1850) (Hemihoplitidae, Upper Barremian). Annales de Paléontologie 100(3), 217-236.

Bert, D., [],2014b. L’influence de la variabilité intraspécifique sur la taxinomie, la biostratigraphie et l'évolution des ammonites: une approche paléobiologique. Exemples pris dans le Jurassique supérieur et le Crétacé inférieur. Thèse Université de Rennes 1, 736 p. (inédit) 
Bulot, L.G., Frau, C., Pictet, A., 2018. Revision of Toxoceratoides royeri (d'Orbigny,1842) and its bearing on the systematics of the Aptian Acrioceratidae Vermeulen, 2004 (Ammonoidea, Ancyloceratina, Ancyloceratoidea). Cretaceous Research 88, 187-196.

Casey, R., 1960. A monograph of the Ammonoidea of the Lower Greensand, part 1. Palaeontographical Society (1959), i-xxxxvi + 1-44.

Casey, R., 1961a. A monograph of the Ammonoidea of the Lower Greensand, part II. Palaeontographical Society (1960), 41-118.

Casey, R., 1961b. A monograph of the Ammonoidea of the Lower Greensand, part III. Palaeontographical Society (1961), 119-216.

Casey, R., 1961c. The stratigraphical palaeontology of the Lower Greensand. Palaeontology 3, 487-621.

Casey, R., Bayliss, H.M., Simpson, M.I., 1998. Observations on the lithostratigraphy and ammonite succession of the Aptian (Lower Cretaceous) Lower Greensand of Chale Bay, Isle of Wight, UK. Cretaceous Research 19, 511-535.

Collignon, M., 1962. Atlas des fossiles caractéristiques de Madagascar (Ammonites). Fascicule II (Aptien). Service Géologique, Tananarive, 65 p. 
Corroy, G., 1925. Le Néocomien de la bordure orientale du Bassin de Paris. Imprimerie J. Coubé \& Fils, Nancy, 334 p.

Cotteau, G. (1853-1857). Étude sur les mollusques fossiles du département de l'Yonne. Premier fascicule comprenant l'introduction et le prodrome. J.-B. Baillières et fils (Paris, London), i-xliij + $141 \mathrm{p}$.

De Baets, K., Bert, D., Hoffmann, R., Monnet, C., Yacobucci, M.M., Klug, C., 2015. Ammonoid intraspecific variability. In: Klug, C., Korn, D., De Baets, K., Kruta,I., Mapes, R.H. (eds.), Ammonoid paleobiology: from anatomy to ecology. Topics in Geobiology 43, $359-426$.

Delanoy, G., 1997. Biostratigraphie des faunes d'ammonites à la limite Barrémien-Aptien dans la région d'Angles-Barrême-Castellane. Étude particulière de la famille des Heteroceratina SPATH, 1922 (Ancyloceratina, Ammonoidea). Annales du Muséum d'Histoire Naturelle de Nice 12, 270 p.

Dimitrova, N., 1967. Fossils of Bulgaria. IV. Lower Cretaceous Cephalopoda (Nautiloidea \& Ammonoidea). Bulgarian Academy of Sciences, Sofia, 424 p. (in Bulgarian).

Donovan, D.T., Callomon, J.H., Howarth, M.K., 1981. Classification of the Jurassic Ammonitina. In: House, M.R., Senior, J.R. (eds.), The Ammonoidea, Special Publications 18. The Systematics Association, Academic Press, 101-155. 
Forbes, E., 1845. Report on the fossils from Santa Fe de Bogota. Quarterly Journal of the Geological Society of London Second Series 4, 174-179.

Gauthier, H. with the collaboration of Busnardo, R., Combemorel, R., Delanoy, G., Fischer, J.-C., Guerin-Franiatte, F., Joly, B., Kennedy, W.J., Sornay, J., Tintant, H., 2006. Révision critique de la Paléontologie Française d'Alcide d'Orbigny, Vol. IV, Céphalopodes Crétacés, sous la direction de J.C. Fischer. Backhuys Publisher, Leiden, 292 p.

Hammer, O., Harper, D.A.T., Ryan, P.D., 2001. PAST: Paleontological Statistics Software Package for Education and Data Analysis. Palaeontologia Electronica 4(1), 9 p.

Haug, E., 1889. Beitrag zur Kenntniss der oberneocomen Ammonitenfauna der Puezalpe bei Corvara (Südtirol). Beitrage zur Palaeontologie und Geologie Osterreich-Ungams und des Orients 7, 193-231.

Hoffmann, R., Weinkauf, M. F. G, Wiedenroth, K., Goeddertz, P., De Baets, K., 2019. Morphological disparity and ontogeny of the endemic heteromorph ammonite genus Aegocrioceras (early Cretaceous, Hauterivian, NW-Germany). Palaeogeography, Palaeoclimatology, Palaeoecology 520, 1-17.

Kakabadze, M. V., Hoedemaeker, P. J., 2004. Heteromorphic ammonites from the Barremian and Aptian strata of Colombia. Scripta Geologica 128, 39-182. 
Kemper, E., 1971. Geologischer Führer durch die Grafschatl Bentheim und die angrenzenden Gebiete. Heimatverein der Grafschaft Bentheim Nordhorn. 4. Auflage, 172 p.

Kemper, E., 1976. Geologischer Führer durch die Grafschaft Bentheim und die angrenzenden Gebiete mit einem Abriss der emslandischen Unterkreide. 5. Auflage. Heimatverein der Grafschatl Bentheim. Nordhom, 206 p.

Kemper, E., 1995. Die Entfaltung der Ammoniten und die Meeresverbindungen im borealen Unter- und Mittel-Apt. Geologisches Jahrbuch Reihe A 141, 171-199.

Kilian, W., 1913. Erste Abteilung: Unterkreide (Palaeocretacicum). Lieferung 2: Das bathyale Palaeocretacicum im sudostlichen Frankreich; Apt-Stufe; Urgonfacies im südostlichen Frankreich, In: Frech, F., Lethaea Geognostica. 1l. Das Mesozoicum, Band 3 (Kreide) (19071913). Schweizerbart. Stuttgart, 289-398.

Kilian, W., Reboul, P., 1915. Contribution a l'étude des faunes paléocretacées du Sud-Est de la France. I. La faune de I'Aptien inferieur des environs de Montélimar (Drôme). Mémoires pour servir a l'explication de la carte géologique détaillée de la France, 3-94.

Kin, A., 2010. Early Maastrichtian ammonites and nautiloids from Hrebenne, southeast Poland, and phenotypic plasticity of Acanthoscaphites tridens (Kner, 1848). Cretaceous Research 31, 27-60. 
Klein, J., Busnardo, R., Company, M., Delanoy, G., Kakabadze, M., Reboulet, S., Ropolo, P., Vašíček, Z., Vermeulen, J., 2007. Lower Cretaceous Ammonites III. Bochianitoidea, Protancyloceratoidea, Ancyloceratoidea, Ptychoceratoidea. In: Riegraf, W. (Ed.), Fossilium Catalogus I: Animalia. Backhuys Publishers, The Netherlands, 381 p.

Klinger, H.C., Kennedy, W.J., 1977. Cretaceous fauna from Zululand, South Africa and Southern Mozambique. The Aptian Ancyloceratidae (Ammonoidea). Annals of the South African Museum 73, 215-359.

Lambert, J., 1916,. Le Néocomien dans le bassin de Paris. Bulletin de la Société Géologique de France (4), 16, 219-225.

Landman, N.H., 1987. Ontogeny of Upper Cretaceous (Turonian-Santonian) scaphitid ammonites from the Western Interior of North America: systematics, developmental patterns, and life history. Bulletin of the American Museum of Natural History 185(2), 117-241.

Lauriat-Rage, A., 2002. La collection d'invertébrés fossiles d'Alcide d'Orbigny et la salle d'Orbigny. Comptes Rendus Palévol 1(7), 615-627.

Lea, I., 1841. Notice of the oolitic formation in America, with descriptions of some of its organic remains. Transactions of the American Philosophical Society VII (new series) 251260. 
Lehmann, J., Friedrich, O., von Bargen, D., Hemker, T., 2012. Early Aptian bay deposits at the southern margin of the Lower Saxony Basin: integrated stratigraphy, palaeoenvironment and OAE 1a. Acta Geologica Polonica 62(1), 35-62

Malkoč, M., Mutterlose, J, Pauly, S., 2010. Timing of the Early Aptian d13C excursion in the Boreal Realm. Newsletter on Stratigraphy 43(3), 251-273.

Matamales-Andreu, R., Company, M., 2019. Morphological variability patterns in the Balearites-Pseudothurmannia genera boundary (Ammonoidea, late Hauterivian): taxonomic and biostratigraphic implications. Journal of Systematic Palaeontology 1-27, http://dx.doi.org/10.1080/14772019.2018.1497718

Mikhailova, I.A., Baraboshkin, E.Y., 2001. First Finds of Lithancylus Casey, 1969 (Ammonoidea, Ancyloceratidae) in the Lower Aptian of Ul'yanovsk Povolzhie (Volga Region). Paleontological Journal 35(4), 367-378.

Moreno-Bedmar, J.A., Company, M., Bover-Arnal, T., Salas, R., Delanoy, G., Martinez, R., Grauges, A., 2009. Biostratigraphic characterization by means of ammonoids of the lower Aptian Oceanic Anoxic Event (OAE 1a) in the eastern Iberian Chain (Maestrat Basin, eastern Spain). Cretaceous Research 30, 864-872.

Murphy, M.A., 1975. Paleontology and stratigraphy of the lower Chickabally mudstone (Barremian-Aptian) in the Ono Quadrangle, northern California. University of California Publications in Geological Sciences 113, 52 p. 
Neumayr, M., Uhlig, V., 1881. Ueber Ammonitiden aus der Hilsbildungen Nordeutsclands. Palaeontographica 27, 129-203.

Obata, I., Ogawa, Y., 1976. Ammonites Biostraligraphy of the Cretaceous Arida Formation, Wakayama Prefecture. Bulletin National Science Museum, Serie C (Geology) 2(2), 93-110.

Orbigny, A., d', 1841-1842. Paléontologie Française. Tome premier. Terrains crétacés. Céphalopodes. Imprimerie Masson, Paris, 662 p.

Orbigny, A., d', 1850. Prodrome de Paléontologie stratigraphique universelle des animaux mollusques \& rayonnes, faisant suite au cours élémentaire de paléontologie et de géologie stratigraphiques. Volume 2. Imprimerie Masson, Paris, 427 p.

Péron, A., 1905. Note stratigraphique sur l'étage Aptien dans l'Est du bassin parisien. Bulletin de la Société Géologique de France 4(5), 359-378.

Reboulet, S., Rawson, P.F., Moreno-Bedmar, J.A. (reporters), Aguirre-Urreta, M.B., Barragan, R., Bogolomov, Y., Company, M., Gonzalez-Arreola, C., Stoyanova, V.I., Matrion, B., Mitta, V., Randrianaly, H., Vašíček, Z., Baraboshkin, E.J., Bert, D., Bersac, S., Bogdanova, T.N., Bulot, L.G., Latil, J.L., Mikhailova, I.A., Ropolo, P., Szives, O., 2011. Report on the 4th International Meeting of the IUGS Lower Cretaceous Ammonite Working Group, the "Kilian Group" (Dijon, France, 30th August 2010). Cretaceous Research 32, 786793. 
Reboulet, S., Szives, O., Aguirre-Urreta, B., Barragan, R., Company, Frau, C., M., Kakabadze, M.V., Klein, J., Moreno-Bedmar, J.A., Lukeneder, A., Pictet, A., Ploch, I., Raisossadat, S.N., Vašíček, Z., Baraboshkin, E.J., Mitta, V.V., 2018. Report on the $6^{\text {th }}$ International Meeting of the IUGS Lower Cretaceous Ammonite Working Group, the "Kilian Group" (Vienna, Austria, 20 ${ }^{\text {th }}$ August 2017). Cretaceous Research 91, 100-110.

Roch, E., 1927. Étude stratigraphique et paléontologique de l'Aptien inférieur de la Bédoule (près Cassis) (Bouches-du-Rhône). Mémoires de la Société Géologique de France 4, série 8, $5-37$.

Ropolo, P., 1995. Implications of variation in coiling in some Hauterivian (Lower Cretaceous) heteromorph ammonites from the Vocontian basin, France. Memorie Descrittive della Carta Geologica d'Italia 51, 137-16.

Ropolo, P., Conte, G., Gonnet, R., Masse, J.-P., Moullade, M., 1998. Les faunes d'ammonites du Barrémien supérieur/Aptien inférieur (Bédoulien) dans la région stratotypique de CassisLa Bédoule (SE France): état des connaissances et propositions pour une zonation par Ammonites du Bédoulien-type. Géologie Méditerranéenne 25(3-4), 167-175.

Ropolo, P., Gonnet, R., Conte, G., 1999. The 'Pseudocrioceras interval' and adjacent beds at La Bédoule (SE France): implications to highest Barremian/lowest Aptian biostratigraphy. Scripta Geologica Special Issue 3, 159-213. 
Ropolo, P., Moullade, M., Conte, G., Tronchetti, G., 2008. About the stratigraphic position of the Lower Aptian Roloboceras hambrovi (Ammonoidea) level. Carnets de Géologie/Notebooks on Geology, 2008/03 [CG2008 L03]), 7 p.

Rouget, I., 2002. Reconstruction phylogenétique chez les ammonites: confrontation des approches cladistiques et stratigraphique. Le cas des Dayiceras (Ammonoidea, Eodeoceratoidea). Thèse Université de Bourgogne, Dijon, 283 p. (inédit).

Sarkar, S.S., 1955. Révision des ammonites déroulées du Crétacé inférieur du Sud-est de la France. Mémoires de la Société géologique de France 72, 176 p.

Spath, L.F., 1930. On some Ammonoidea from the Lower Greensand. Annals and Magazine of Natural History, London, Serie 10(5), 417-464.

Stchépinsky, V., 1962. Histoire géologique de la Haute-Marne et des régions voisines. SaintDizier ed., 223 p.

Thomel, G., Coulet, P., Davoux, J., Delanoy, G., Führ, F., Führ, M., Gazel, L., Giverso, J., Jullian, H., Jullian, V., Levan, G., Mascarelli, E., Maurel, L., Poupon, A., Salomon, M., 1990. Le genre Acrioceras Hyatt, 1900 dans le Barrémien du Sud-Est de la France. Annales du Muséum d'Histoire Naturelle de Nice 7, 20-151. 
Toshimitsu, S., Hirano, H., 2000. Database of the Cretaceous ammonoids in Japan: stratigraphic distribution and bibliography. Bulletin of the Geological Survey of Japan 51(11), 559-613.

Uhlig, V., 1883. Die Cephalopodenfauna der Wernsdorfer Schichten. Denkschriften der Kaiserlichen Akademie der Wissenschaften, Wien, mathematisch-naturwissenschaftliche Classe 46, 127-290.

Vermeulen, J., Lazarin, P., 2007. Nouvelles données sur les Ancyloceratoidea Gill, 1871 (Ancyloceratina Wiedmann, 1966 emend. Vermeulen, 2005) du Barrémien supérieur et de l'Aptien inférieur. Annales du Muséum d'Histoire Naturelle de Nice 22, 27-86.

Von Koenen, A., 1902. Die Ammonitiden des Norddeutschen Neocom (Valanginien, Hauterivien, Barremien und Aptien). Abhandlungen der Königlich Preussischen Geologischen Landesanstalt und Bergakademie, Neue Folge, Berlin. Heft 24, 451 p.

Wiedmann, J., Kulmann, J., 1981. Ammonoid suture in ontogeny and phylogeny. In: House, M.R., Senoir, J.R. (Eds.), The Ammonoidea. Systematic Association special volume 18. Academic Press, London and New York, pp. 215-255.

\section{Figures}


Fig. 1. Explanatory figure of the measured shell parameters. 1: spiral; 2: proversum; 3: flexus; 4: retroversum; Ds: diameter of the spiral; $\mathrm{H}$ : whorl height measured at the top of the flexus; L: total length of the shell; W: whorl width measured at the top of the flexus (figured specimen: No. SU.PAL.2019.0.290, Pierre et Marie Curie University's collection, Paris, France). Naming of the parts of the shell according to Bulot et al., (2017, fig. 1)

Paramètres de mesure de la coquille utilisés dans le présent travail. 1: spire; 2: proversum; 3: flexus; 4: retroversum; Ds: diamètre de la spire; H: hauteur de tour mesurée au sommet du flexus; L: taille de la coquille; W: épaisseur du tour mesurée au sommet du flexus (spécimen figuré: $n^{\circ}$ SU.PAL.2019.0.290, collections de l'Université Pierre et Marie Curie, Paris, France). Nomenclature des différentes parties de la coquille d'après Bulot et al. (2017, fig. 1).

Fig. 2. Map of the studied area with main towns and locations of historical outcrops of the Argiles à Plicatules Formation that yielded the sample studied in the present work. Broken dark line: limits of the Anglo-Paris Basin. Magnification map of the eastern Paris Basin: Argiles à Plicatules Formation subsurface outcrops shown in solid grey, rivers and lakes in solid black. Map after Amédro and Matrion (2004, amended).

Carte du secteur d'étude avec villes principales et localisation des affleurements historiques des Argiles à Plicatules ayant livré l'échantillon étudié dans le présent travail. Ligne en pointillés noirs : limites du bassin angloparisien. Carte détaillant l'Est du Bassin de Paris : affleurements de subsurface des Argiles à Plicatules en gris, lacs et cours d'eau en noir. Carte d'après Amédro et Matrion (2004), modifié. 
Fig. 3. Ancyloceras varians d'Orbigny, 1842 from the Argiles à Plicatules. A1-A3: plaster cast No. SU.PAL.2019.0.290 of an unfound original specimen from Sommelonne, Pierre et Marie Curie University's collection (Paris). B1, B2: specimen No. 753758, Louvemont, Saint Dizier Municipal Museum's collection. C1, C2: specimen No. SU.PAL.2018.0.1.5, Sommelonne, Tombeck's collection, Pierre et Marie Curie University (Paris). D1, D2: specimen No. SU.PAL.2019.0.291, locality unknown, Pierre et Marie Curie University’s collection (Paris). E: specimen No. SU.PAL.2019.0.292, Sommelonne, Pierre et Marie Curie University's collection (Paris). F1-F3: specimen No. 753769, Louvemont, Cornuel's collection, Saint Dizier Municipal Museum. G1-G3: specimen No. SU.PAL.2019.0.293, locality unknown, Pierre et Marie Curie University's collection (Paris). H1, H2: specimen No. SU.PAL.2019.0.294, Bailly-aux-Forges, Pierre et Marie Curie University’s collection (Paris). I1, I2: specimen No. SU.PAL.2019.0.295, locality unknown, Pierre et Marie Curie University's collection (Paris). J1, J2: specimen No. SU.PAL.2019.0.289.2, Bailly-auxForges, Pierre et Marie Curie University's collection (Paris). K1-K3: specimen No. SU.PAL.2019.0.296, locality unknown, Pierre et Marie Curie University's collection (Paris). L: specimen No. SU.PAL.2019.0.297, locality unknown, Pierre et Marie Curie University’s collection (Paris).

Ancyloceras varians d'Orbigny, 1842 des Argiles à Plicatules. A1-A3: moulage $n^{\circ}$ SU.PAL.2019.0.290 d'un spécimen original non retrouvé, provenant de Sommelonne, collections de l'Université Pierre et Marie Curie (Paris). B1, B2: spécimen $n^{\circ} 753758$, Louvemont, collections du musée municipal de Saint Dizier. C1, C2: spécimen $n^{\circ}$ SU.PAL.2018.0.1.5, Sommelonne, collection Tombeck, Université Pierre et Marie Curie (Paris). D1, D2: spécimen $n^{\circ}$ SU.PAL.2019.0.291, localité inconnue, collections de l'Université Pierre et Marie Curie (Paris). E: spécimen $n^{\circ}$ SU.PAL.2019.0.292, Sommelonne, 
collections de l'Université Pierre et Marie Curie (Paris). F1-F3: spécimen $n^{\circ} 753769$, Louvemont, collection Cornuel, musée municipal de Saint Dizier. G1-G3: spécimen $n^{\circ}$ SU.PAL.2019.0.293, localité inconnue, collections de l'Université Pierre et Marie Curie (Paris). H1, H2: spécimen $n^{\circ}$ SU.PAL.2019.0.294, Bailly-aux-Forges, collections de l’Université Pierre et Marie Curie (Paris). I1, I2: spécimen $n^{\circ}$ SU.PAL.2019.0.295, localité inconnue, collections de l'Université Pierre et Marie Curie (Paris). J1, J2: spécimen $n^{\circ}$ SU.PAL.2019.0.289.2, Bailly-aux-Forges, collections de l'Université Pierre et Marie Curie (Paris). K1-K3: spécimen $n^{\circ}$ SU.PAL.2019.0.296, localité inconnue, collections de l'Université Pierre et Marie Curie (Paris). L: spécimen $n^{\circ}$ SU.PAL.2019.0.297, localité inconnue, collections de l'Université Pierre et Marie Curie (Paris).

Fig. 4. Ancyloceras varians d'Orbigny, 1842 from the Argiles à Plicatules. A1-A3: specimen No. SU.PAL.2019.0.287.1, Sommelonne, Pierre et Marie Curie University's collection (Paris). B1, B2: specimen No. 753755, Louvemont, Saint Dizier Municipal Museum's collection. C1-C3: specimen No. SU.PAL.2019.0.288, locality unknown, Pierre et Marie Curie University's collection (Paris). D1, D2: specimen No. SU.PAL.2019.0.174.4, Baillyaux-Forges, J. Lambert's collection, Pierre et Marie Curie University (Paris). E1-E3: specimen No. SU.PAL.2017.0.48, locality unknown, Pierre et Marie Curie University's collection (Paris). F1, F2: plaster cast No. MNHN.F.A71270 of an unfound original specimen of the Cornuel's collection, Bailly-aux-Forges, Natural History National Museum's collection (Paris). G1-G3: specimen No. SU.PAL.2017.0.49, locality unknown, Pierre et Marie Curie University's collection (Paris). H1, H2: specimen No. SU.PAL.2017.0.40, Sommelonne, Pierre et Marie Curie University's collection (Paris). 
Ancyloceras varians d'Orbigny, 1842 des Argiles à Plicatules. A1-A3: spécimen $n^{\circ}$ SU.PAL.2019.0.287.1, Sommelonne, collections de l'Université Pierre et Marie Curie (Paris). B1, B2: spécimen $n^{\circ} 753755$, Louvemont, collections du musée municipal de Saint Dizier. C1-C3: spécimen $n^{\circ}$ SU.PAL.2019.0.288, localité inconnue, collections de l’Université Pierre et Marie Curie (Paris). D1, D2: spécimen $n^{\circ}$ SU.PAL.2019.0.174.4, Bailly-aux-Forges, collection J. Lambert, Université Pierre et Marie Curie (Paris). E1-E3: spécimen $n^{\circ}$ SU.PAL.2017.0.48, localité inconnue, collections de l'Université Pierre et Marie Curie (Paris). F1, F2: moulage $n^{\circ}$ MNHN.F.A71270 d'un spécimen original non retrouvé de la collection Cornuel, provenant de Bailly-aux-Forges, collections du Muséum National d'Histoire Naturelle (Paris). G1-G3: spécimen $n^{\circ}$ SU.PAL.2017.0.49, localité inconnue, collections de l'Université Pierre et Marie Curie (Paris). H1, H2: spécimen $n^{\circ}$ SU.PAL.2017.0.40, Sommelonne, collections de l'Université Pierre et Marie Curie (Paris).

Fig. 5. Ancyloceras varians d'Orbigny, 1842 from the Argiles à Plicatules. A to D: specimens from Ancerville, d'Orbigny's collection, Natural History National Museum (Paris). A1-A4: lectotype, specimen No. MNHN.F.R00847. B1, B2: paralectotype, specimen No. MNHN.F.A57402. C1, C2: paralectotype, specimen No. MNHN.F.A71271. D1, D2: paralectotype, specimen No. MNHN.F.A71272. E1, E2: specimen No. SU.PAL.2017.0.47, locality unknown, Pierre et Marie Curie University's collection (Paris). F1, F2: specimen No. SU.PAL.2019.0.289.1, Sommelonne, Pierre et Marie Curie University's collection (Paris). G1, G2: specimen No. 753762, Louvemont, Saint Dizier Municipal Museum’s collection. H1, H2: specimen No. SU.PAL.2017.0.67.52, Louvemont, Schlumberger's collection, Pierre et Marie Curie University (Paris). I1, I2: specimen No. 753761, Louvemont, Saint Dizier Municipal Museum's collection. 
Ancyloceras varians d'Orbigny, 1842 des Argiles à Plicatules. A à D: spécimens provenant d'Ancerville, collection d'Orbigny, Muséum National d'Histoire Naturelle (Paris). A1-A4: lectotype, spécimen $n^{\circ}$ MNHN.F.R00847. B1, B2: paralectotype, spécimen $n^{\circ}$ MNHN.F.A57402. C1, C2: paralectotype, spécimen $n^{\circ}$ MNHN.F.A71271. D1, D2: paralectotype, spécimen $n^{\circ}$ MNHN.F.A71272. E1, E2: spécimen $n^{\circ}$ SU.PAL.2017.0.47, localité inconnue, collections de l'Université Pierre et Marie Curie (Paris). F1, F2: spécimen $n^{\circ}$ SU.PAL.2019.0.289.1, Sommelonne, collections de l'Université Pierre et Marie Curie (Paris). G1, G2: spécimen $n^{\circ}$ 753762, Louvemont, collections du musée municipal de Saint Dizier. H1, H2: spécimen $n^{\circ}$ SU.PAL.2017.0.67.52, Louvemont, collection Schlumberger, Université Pierre et Marie Curie (Paris). I1, I2: spécimen $n^{\circ}$ 753761, Louvemont, collections du musée municipal de Saint Dizier.

Fig. 6. Lower Aptian ammonite biostratigraphy of southern England according to Casey (1961c) and Casey et al. (1998) and the Anglo-Paris Basin according to Bersac et al. (2012), parallelized with the Standard Zonal Scheme (Reboulet et al., 2018). « St. »: stages; «SZS »: Standard Zonal Scheme; “?”: uncertain data.

Biostratigraphie par ammonites de l'Aptien inférieur du Sud de l'Angleterre d'après Casey (1961c) et Casey et al. (1998) et du bassin anglo-parisien d'après Bersac et al. (2012), mis en parallèle avec le schéma zonal standard (Reboulet et al., 2018). «St. » : étages ; «SZS» : Schéma Zonal Standart ; “?” : donnée incertaine. 
Fig. 7. Relation between the variables analyzed. Results are given for the whole sample only. H, W, R, W/H: see Fig. 1; R2: coefficient of determination; r: coefficient of correlation; $p$ (unc.): probability of uncorrelation between variables.

Relation entre les variables analysées. Les résultats sont ceux de l'échantillon d'étude. $H, W$, R, W/H: voir Fig. 1; R2: coefficient de détermination; $r$ : coefficient de corrélation; $\mathrm{p}($ unc.): probabilité de non corrélation entre les variables.

Fig. 8. Bivariate diagrams. $H, W, R, W / H$ : see Fig. 1. Thick line: regression curve. Dimensions in $\mathrm{mm}$.

Diagrammes bivariés. $H, W, R, W / H$ : voir Fig. 1. Ligne épaisse: courbe de régression. Les dimensions sont en mm.

Fig. 9. Frequency histograms of the values of $H, W$ and $\mathrm{R}$ with results of the Shapiro-Wilk tests. Values in mm. H, W and R: see Fig. 1. Thin curve: Kernel Density Estimator. Thick curve: fitted normality curve. Inverted triangle with thick edges: specimen No. MNHN.F.R00847, lectotype of Ancyloceras varians d'Orbigny, 1842.

Histogrammes de fréquence des valeurs de $H, W$ et $R$ avec résultat des tests de Shapiro-Wilk. Valeurs en mm. H, W et R: voir Fig. 1. Courbe fine : estimation de la densité par noyaux. Courbe épaisse: courbe de normalité ajustée. Triangle inversé avec bords épais: spécimen $n^{\circ}$ MNHN.F.R00847, lectotype d'Ancyloceras varians d'Orbigny, 1842.

Fig. 10. Patterns of morphological variability in the study sample of Ancyloceras varians d'Orbigny, 1842. 
Modalités de la variabilité morphologique de l'échantillon d'étude d'Ancyloceras varians d'Orbigny, 1842.

Table 1. Some basic descriptive statistics of the variables analyzed for each subsample and for the whole study sample ('all subsamples'). H, W, R, W/H: see Fig. 1; Bailly-aux-F.: Bailly-aux-Forges; N: number of studied specimens; Min.: minimum; Max.: maximum; Var.: variance.

Quelques valeurs des variables analysées pour chaque sous-échantillon et pour l'ensemble de l'échantillon d'étude (« all subsamples»). H, W, R, W/H: voir Fig. 1; Bailly-aux-F.: Baillyaux-Forges; Val: valeur des variables; N: nombre de spécimens étudiés; Min: minimum; Max: maximum; Var: variance. 


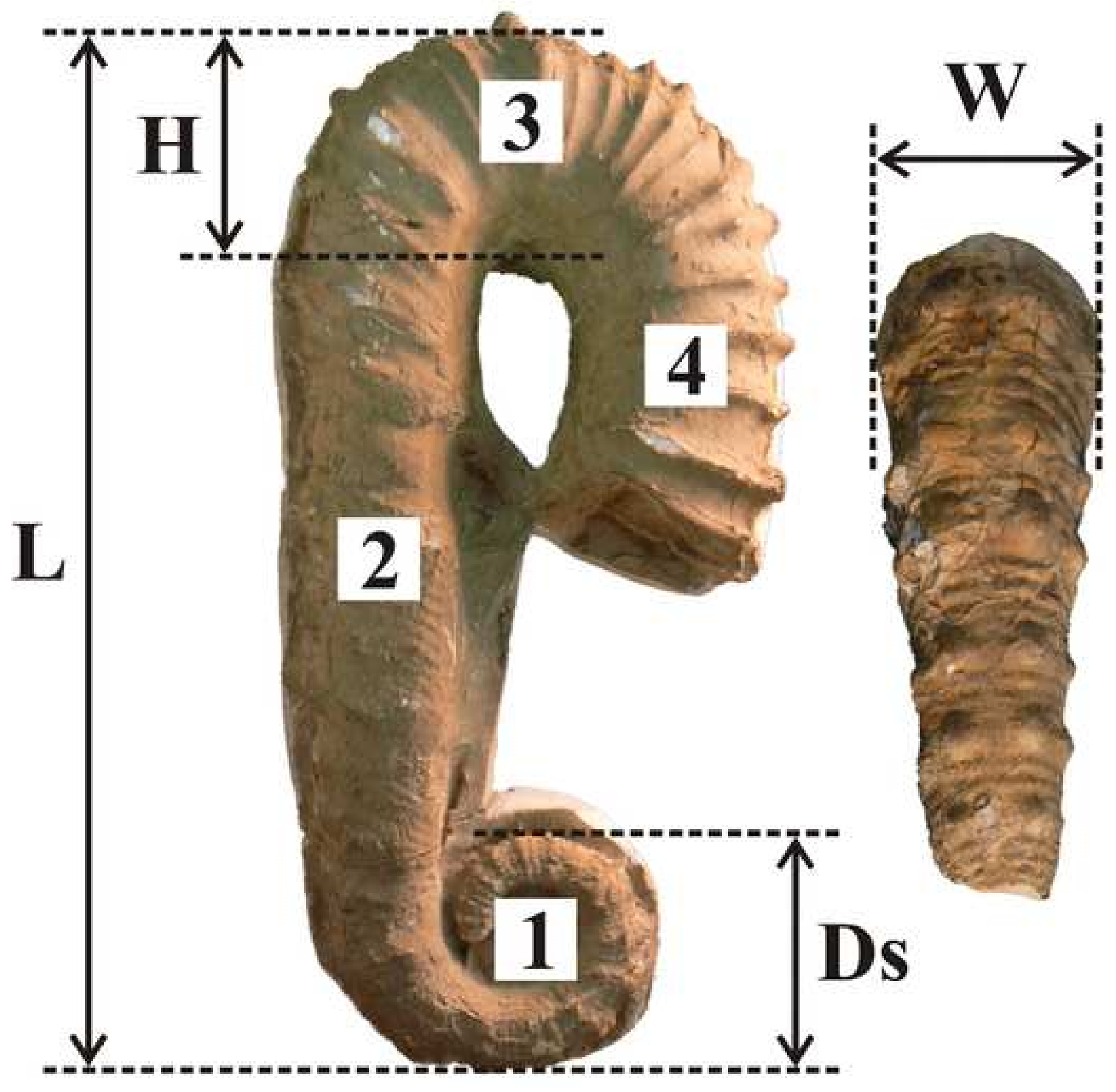




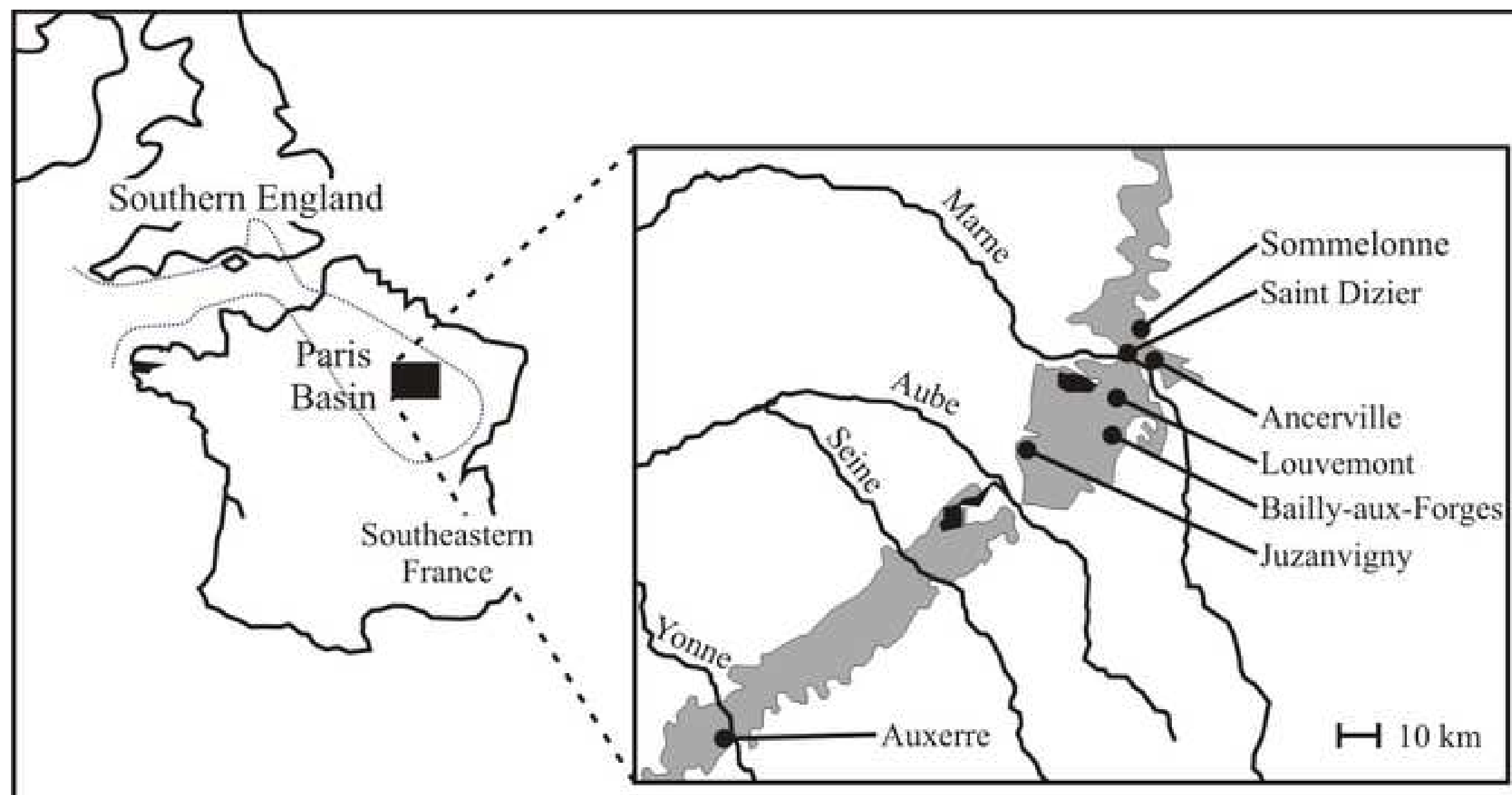



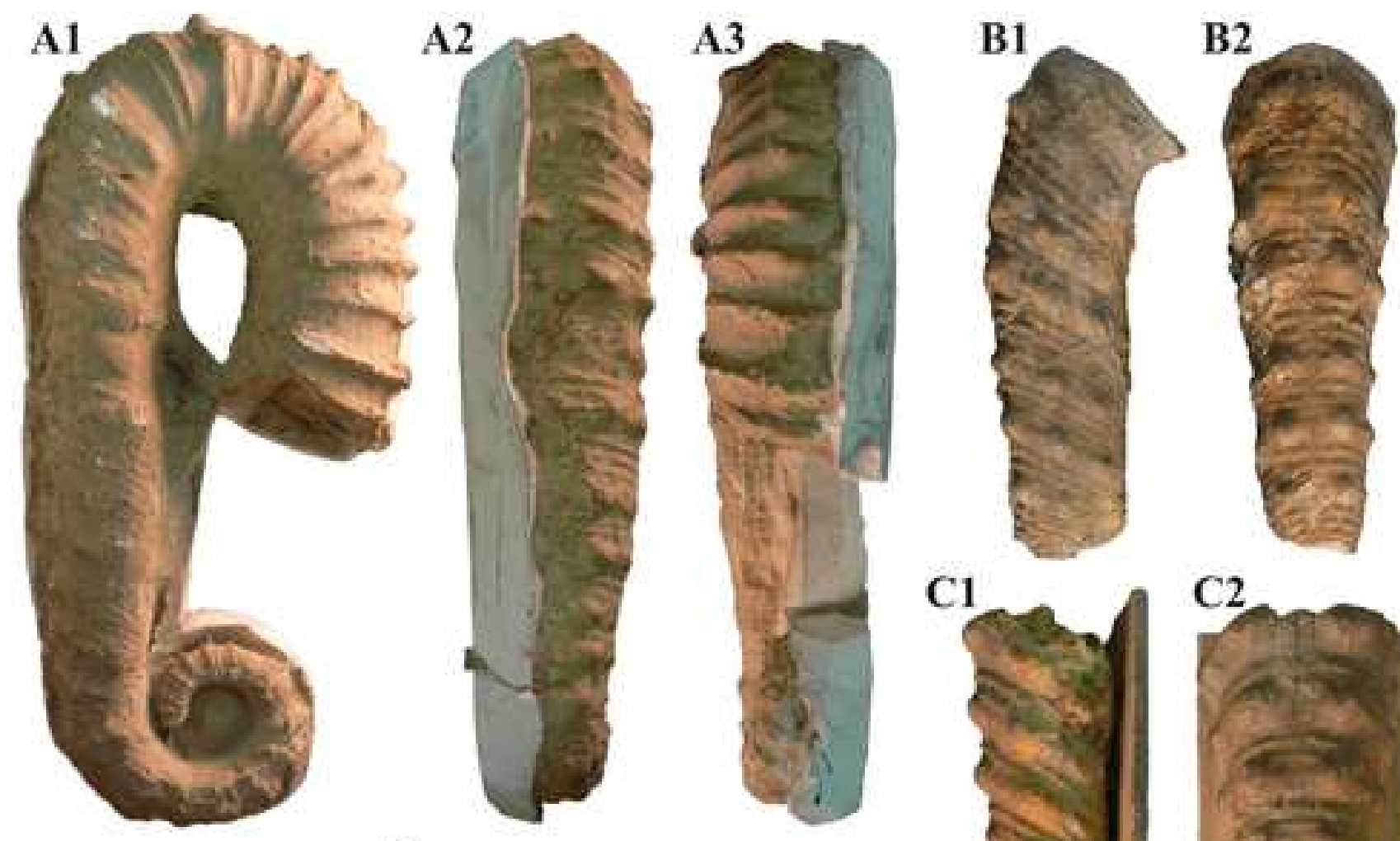

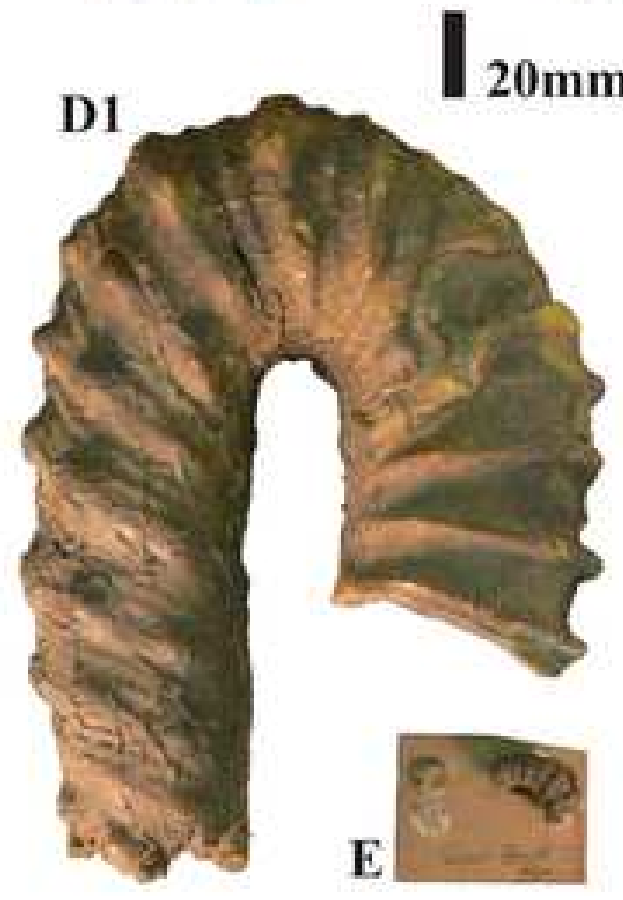

C1

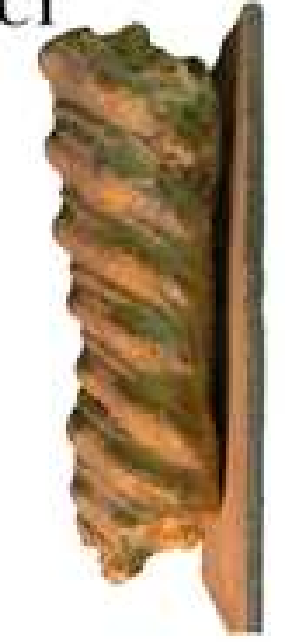

C2

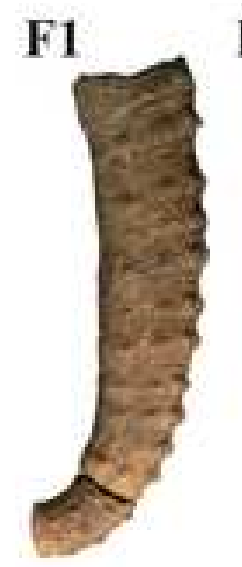

F2
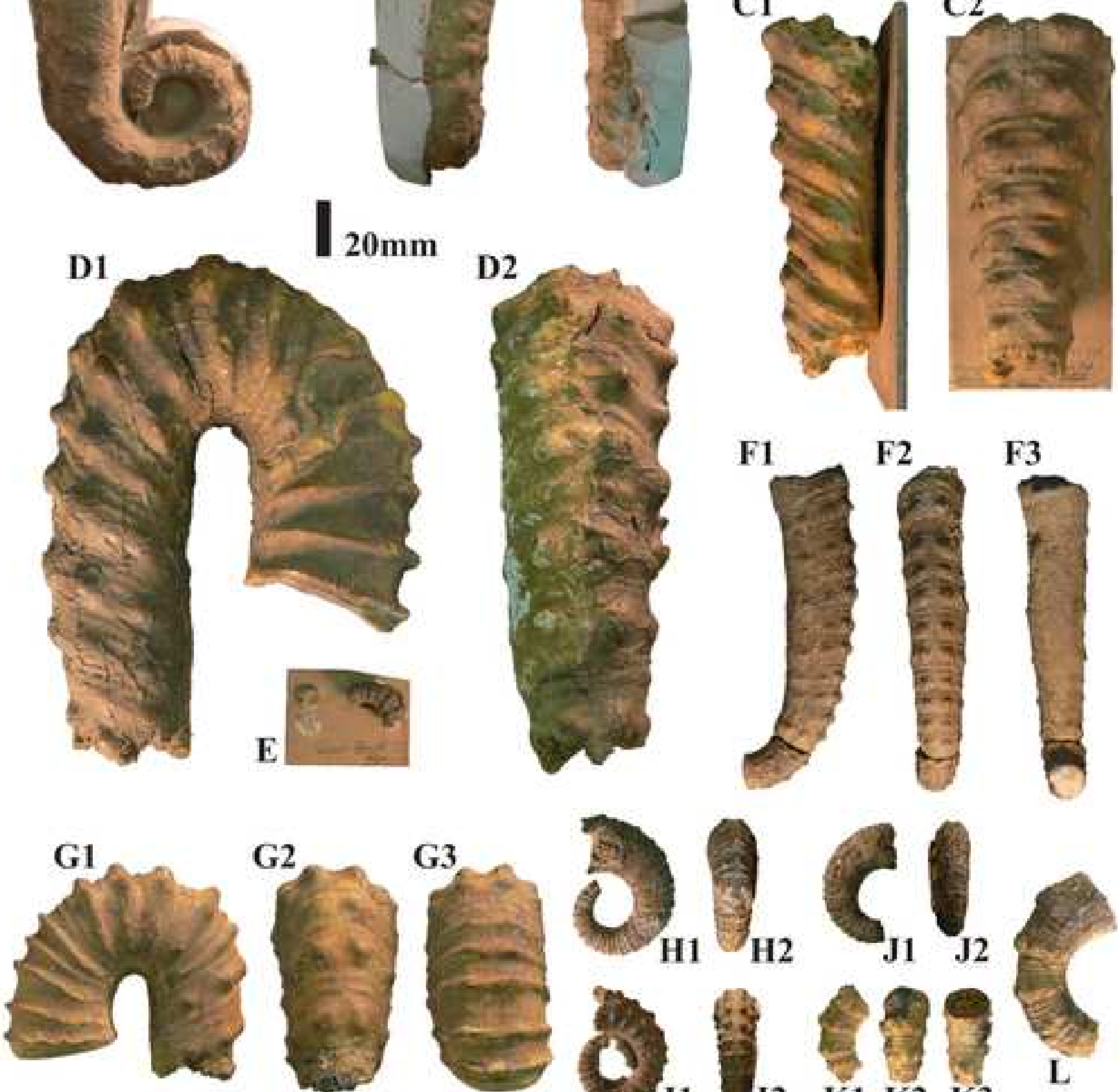
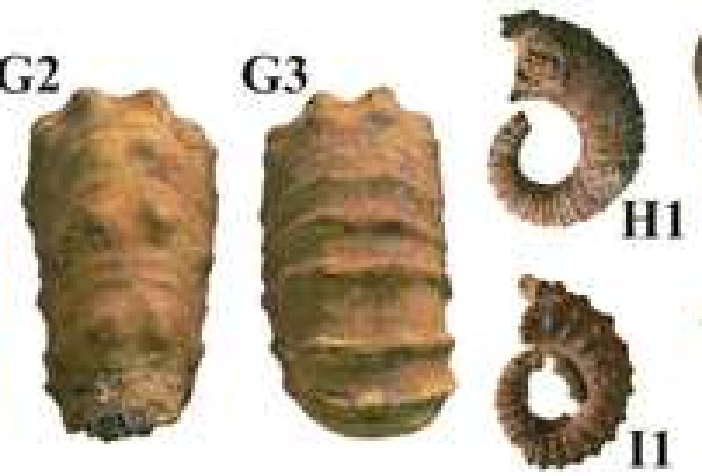
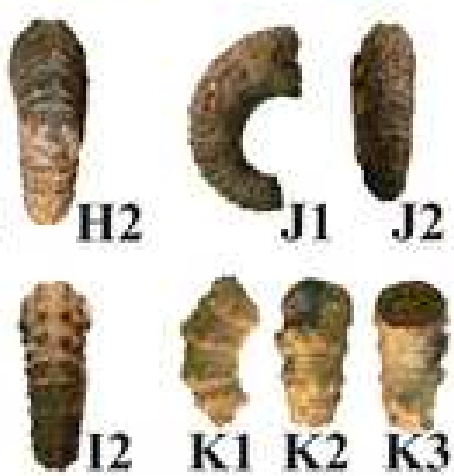

$\begin{array}{llll}2 & \mathrm{~K} 1 & \mathrm{~K} 2 & \mathrm{~K} 3\end{array}$

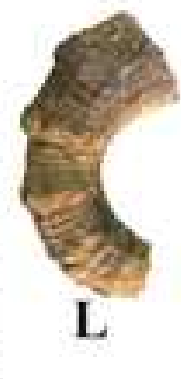



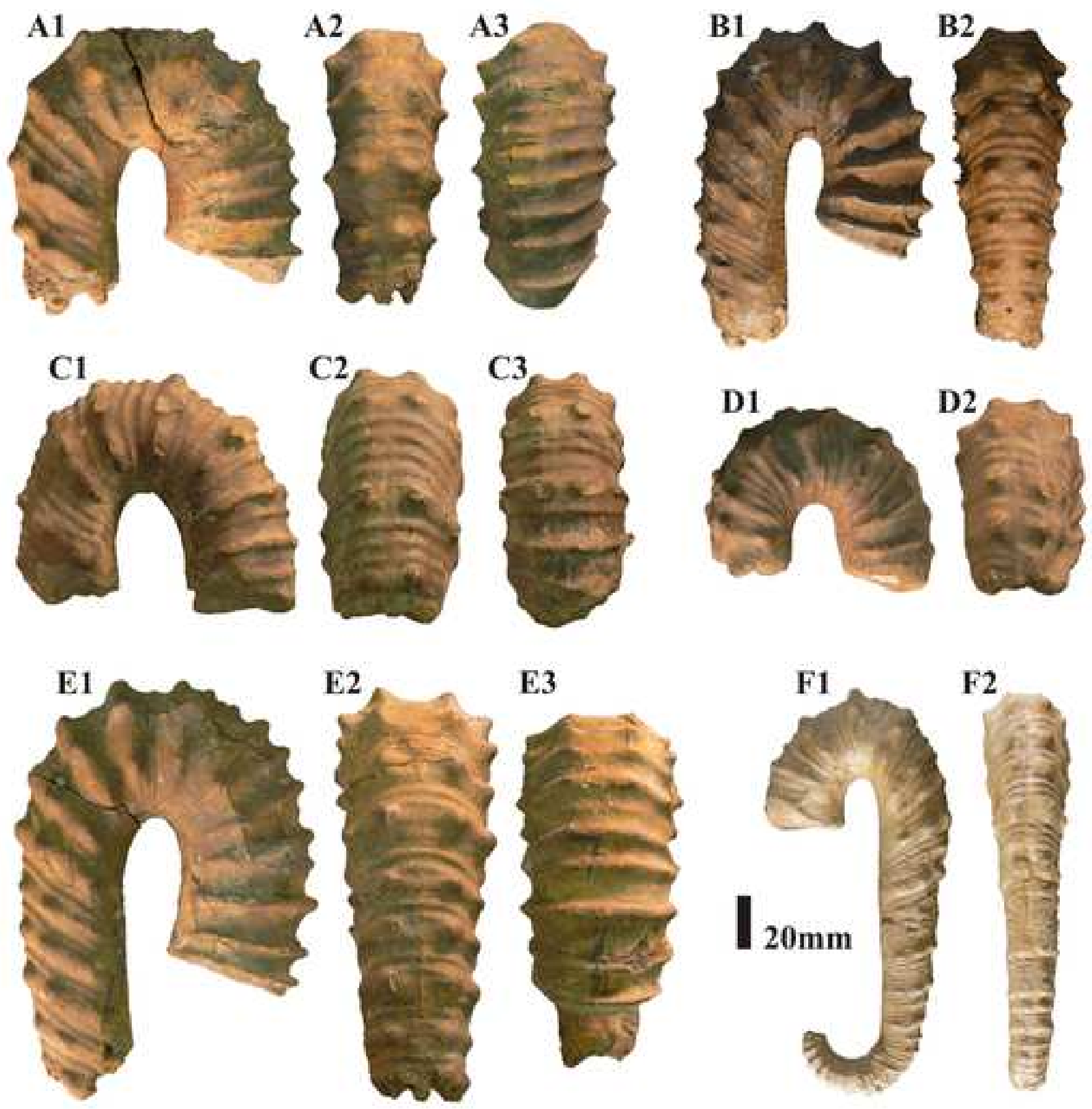

F2
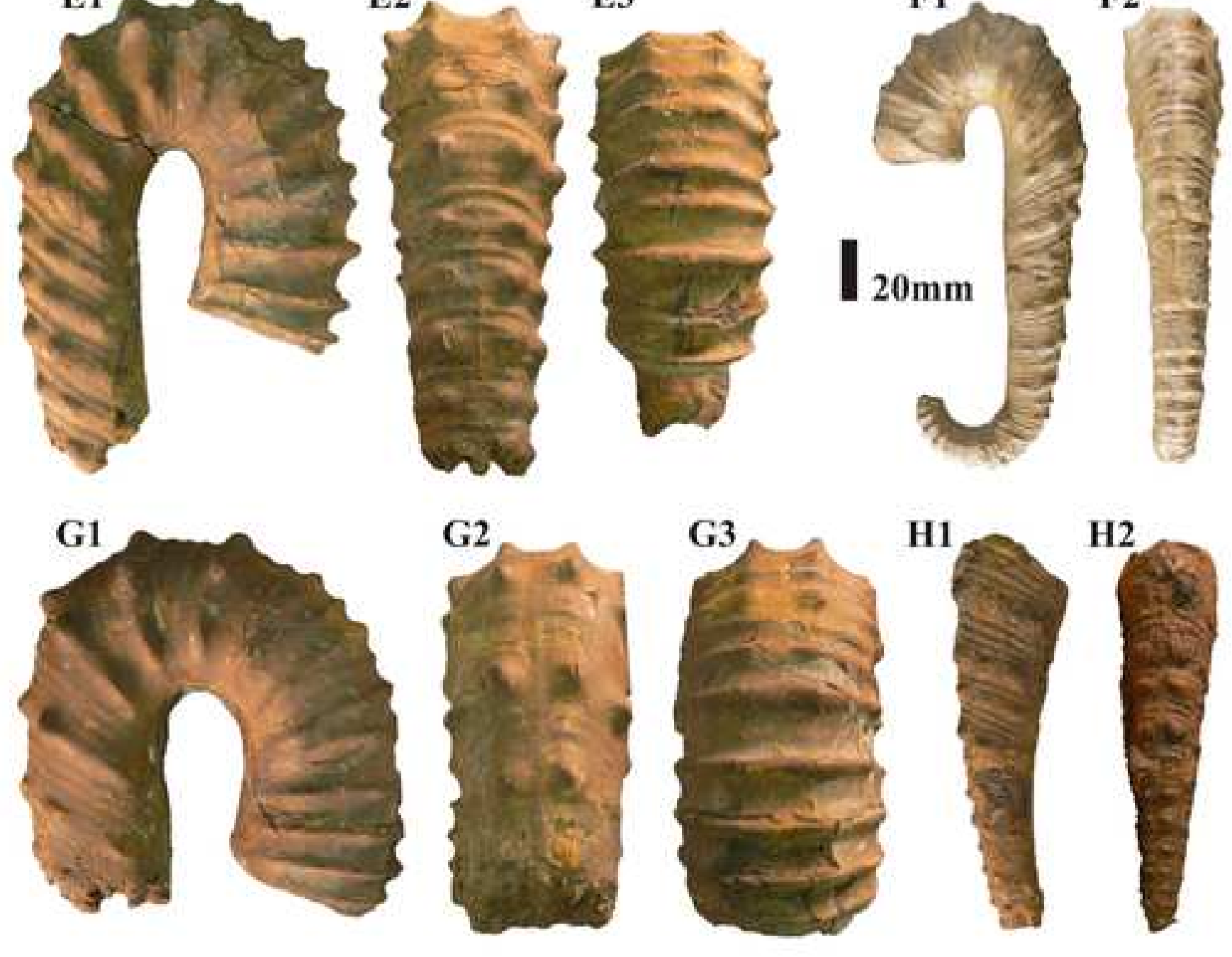




\section{Southern England (Casey, 1961a;}

Casey et al., 1998)

\section{SZS (Reboulet Anglo-Paris B. et al., 2018) (Bersac et al., 2012)}

\begin{tabular}{|c|c|c|c|c|c|c|}
\hline$\dot{n}$ & है & Subzones & 离 & Subzones & 产 & Subzones \\
\hline \multirow{11}{*}{ 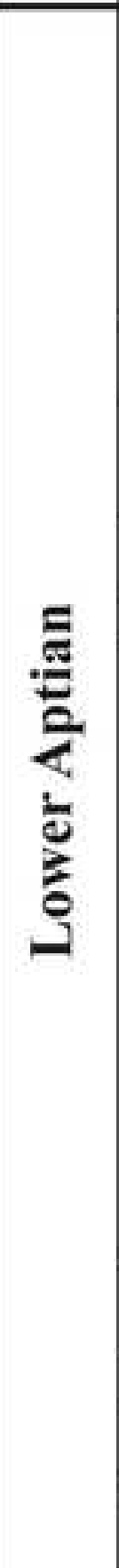 } & \multirow{2}{*}{ 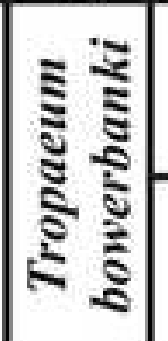 } & $\begin{array}{l}\text { Cheloniceras } \\
\text { meyendorffi }\end{array}$ & \multirow{2}{*}{ 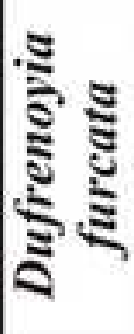 } & $\begin{array}{l}\text { Dufrenoyia } \\
\text { dufrenoyi }\end{array}$ & \multirow{2}{*}{ 竎 } & $\begin{array}{l}\text { Dufrenoyia } \\
\text { dufrenoyi }\end{array}$ \\
\hline & & $\begin{array}{l}\text { Dufrenoyia } \\
\text { transitoria }\end{array}$ & & $\begin{array}{l}\text { Dufrenoyia } \\
\text { furcata }\end{array}$ & & $\begin{array}{l}\text { Dufrenoyia } \\
\text { furcata }\end{array}$ \\
\hline & \multirow{2}{*}{ 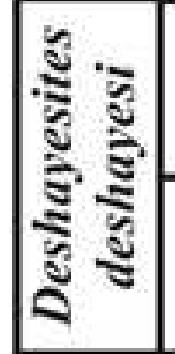 } & $\begin{array}{l}\text { Deshayesites } \\
\text { grandis }\end{array}$ & \multirow{2}{*}{ 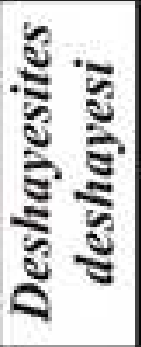 } & $\begin{array}{r}\text { Desha } \\
\text { grai }\end{array}$ & \multirow{3}{*}{ 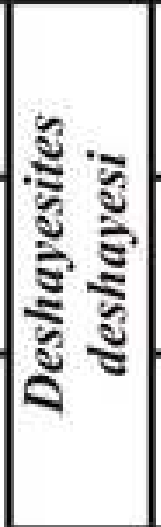 } & $\begin{array}{l}\text { Deshayesites } \\
\text { grandis }\end{array}$ \\
\hline & & $\begin{array}{l}\text { Cheloniceras } \\
\text { parinodum }\end{array}$ & & & & $\begin{array}{c}\text { Deshayesites } \\
\text { multicostatum }\end{array}$ \\
\hline & \multirow{5}{*}{ 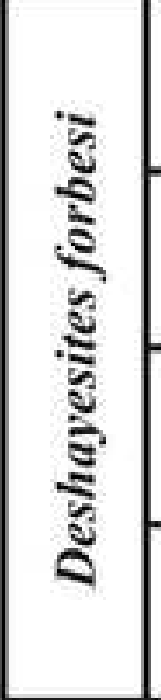 } & $\begin{array}{l}\text { Deshayesites } \\
\text { annelidus }\end{array}$ & \multirow{5}{*}{ 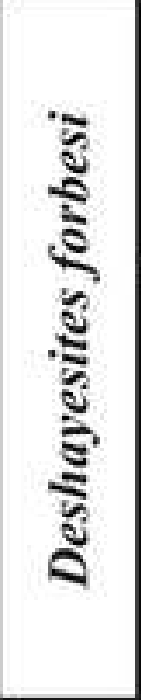 } & \multirow{3}{*}{$\begin{array}{c}\text { Roloboceras } \\
\text { hambrovi } \\
?\end{array}$} & & $\begin{array}{c}\text { Deshayesites } \\
\text { deshayesi }\end{array}$ \\
\hline & & Deshayesites & & & \multirow{4}{*}{ 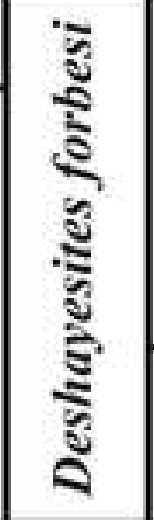 } & \multirow{3}{*}{$\begin{array}{l}\text { Deshayesites } \\
\quad \text { forbesi }\end{array}$} \\
\hline & & camanscis & & & & \\
\hline & & $\begin{array}{c}\text { Deshayesites } \\
\text { kiliani }\end{array}$ & & & & \\
\hline & & $\begin{array}{c}\text { Deshayesites } \\
\text { fittoni }\end{array}$ & & & & $\begin{array}{l}\text { Deshayesites } \\
\text { fittoni }\end{array}$ \\
\hline & \multirow{2}{*}{ 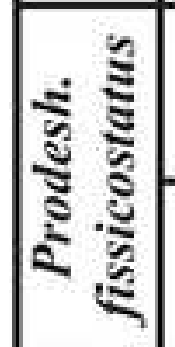 } & $\begin{array}{c}\text { Prodeshayesites } \\
\text { obsoletus }\end{array}$ & \multirow{2}{*}{ 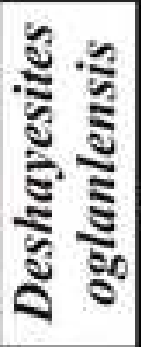 } & $\begin{array}{c}\text { Deshayesites } \\
\text { luppovi }\end{array}$ & \multirow{2}{*}{ 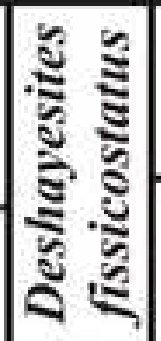 } & $\begin{array}{l}\text { D. fissicostatus } \\
\text { obsoletus }\end{array}$ \\
\hline & & $\begin{array}{c}\text { Prodeshayesites } \\
\text { bodei }\end{array}$ & & & & $\begin{array}{l}\text { D. fissicostatus } \\
\text { fissicostatus }\end{array}$ \\
\hline
\end{tabular}




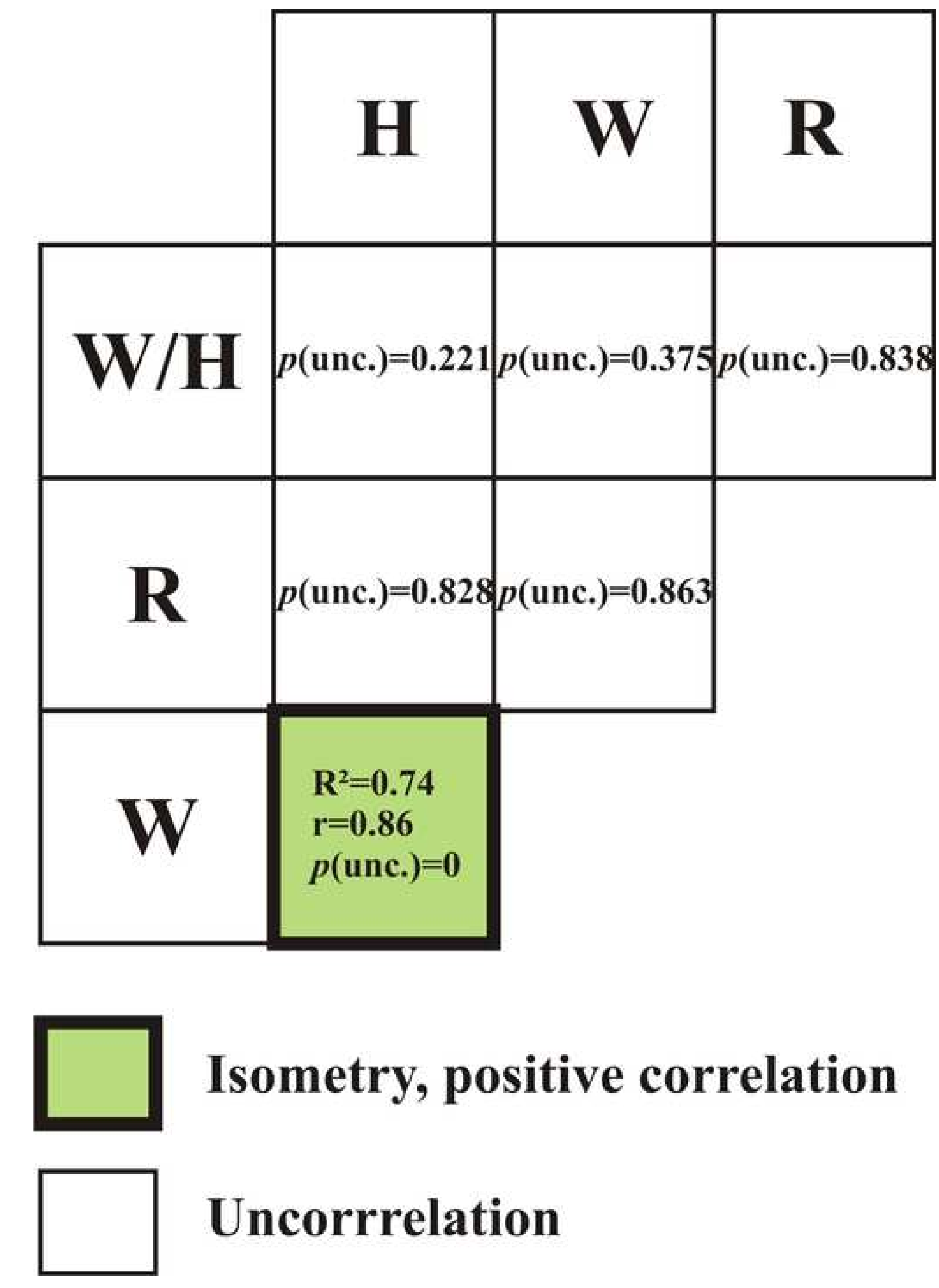



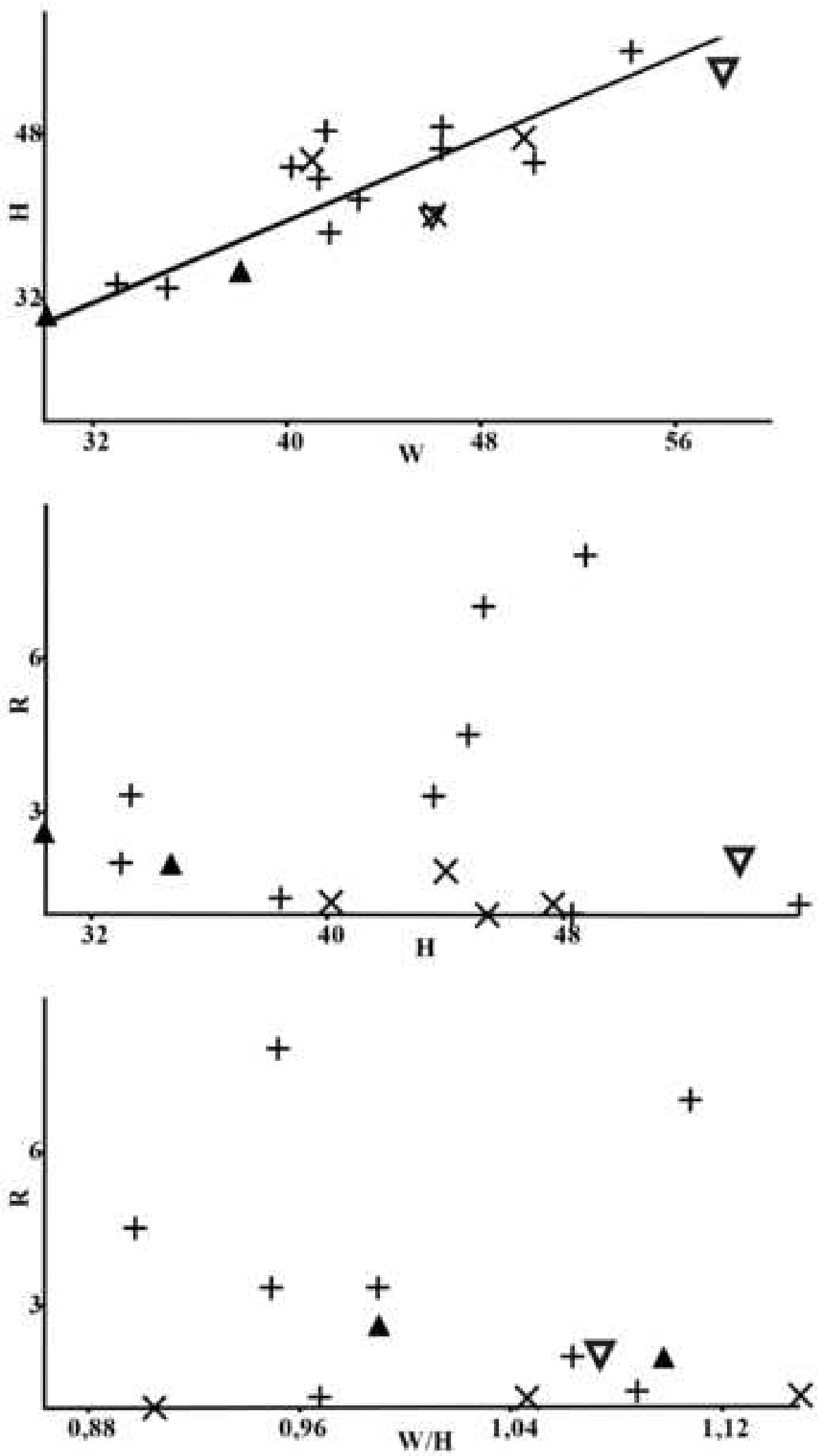

+ Louvemont

A Bailly-aux-Forges

$\nabla$ Ancerville $\times$ Sommelonne Lectotype of Ancyloceras varians d'Orbigny, 1842 (MNHN.F.R00847) 

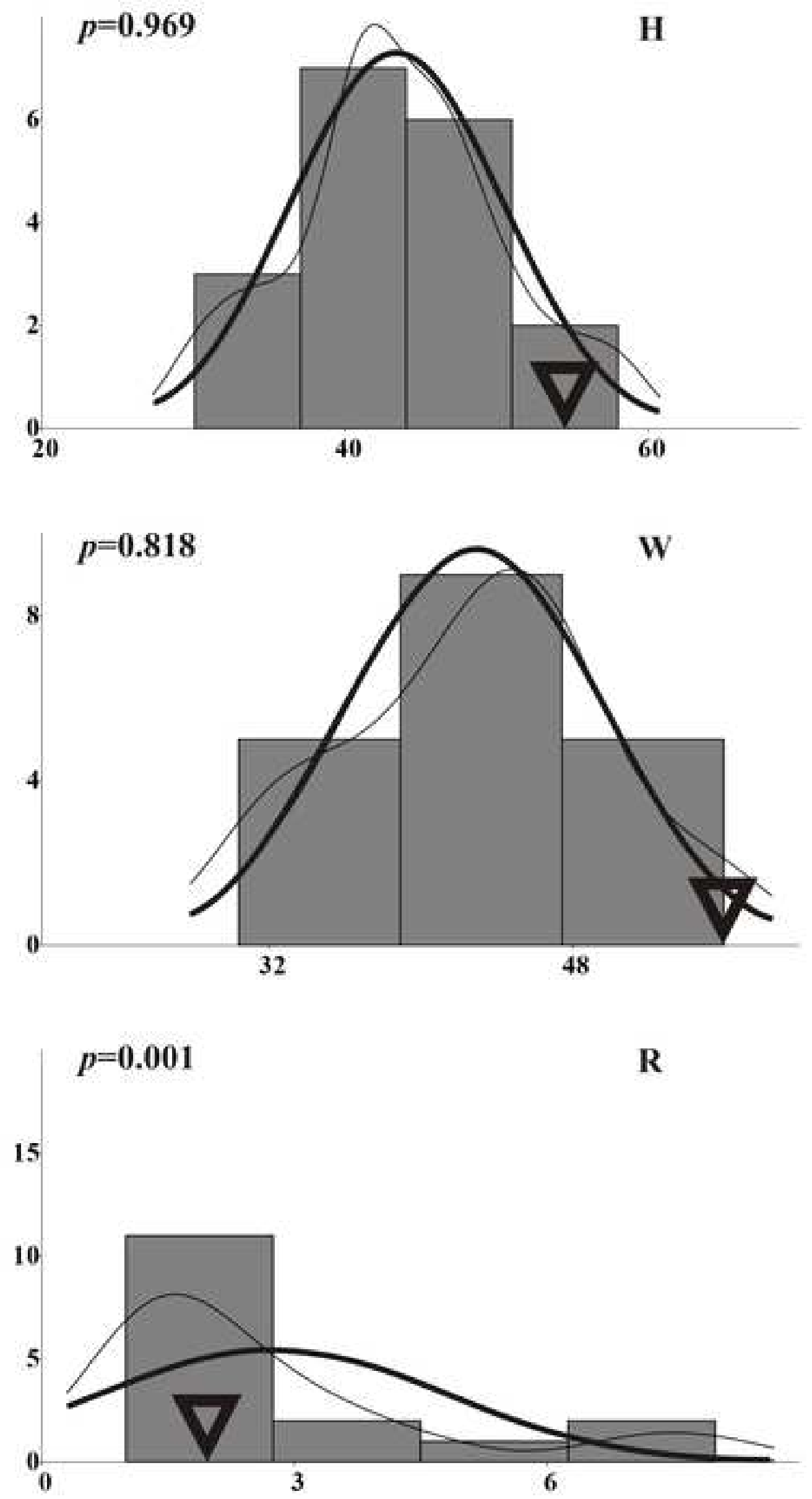


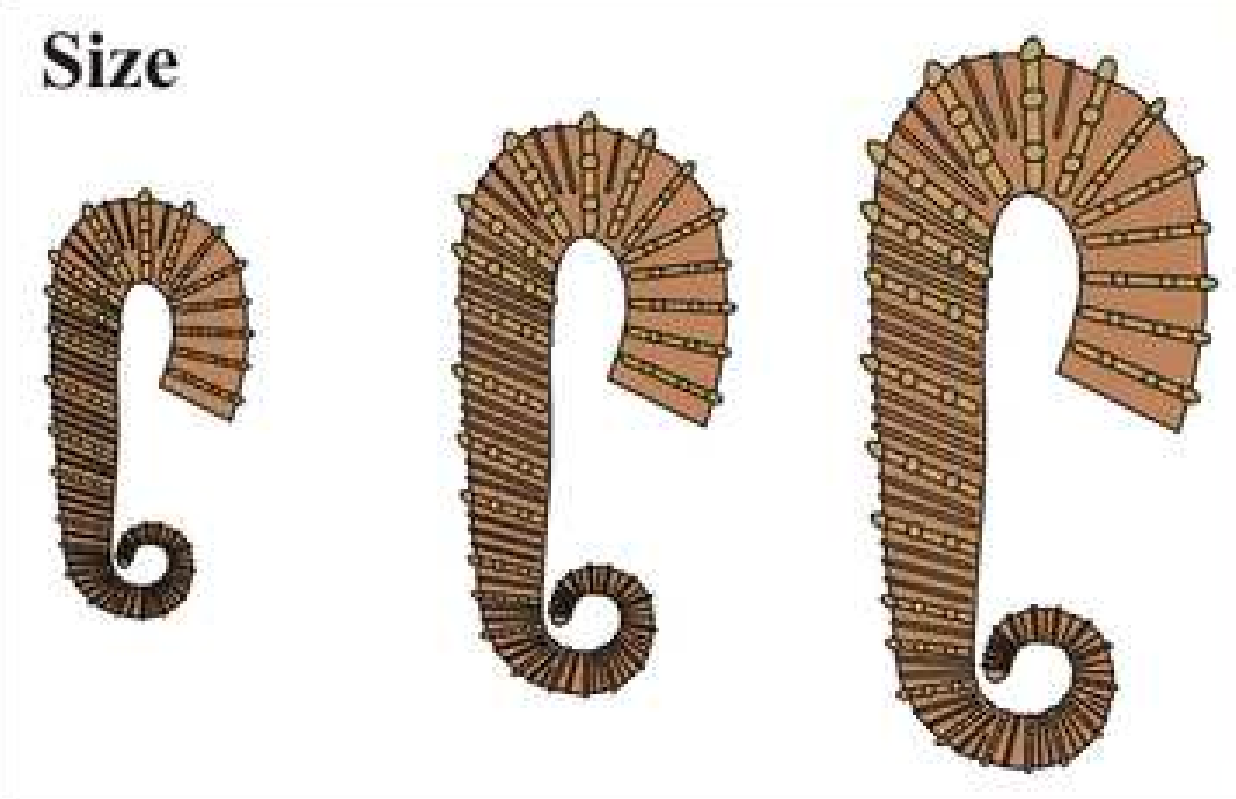

\section{Ornamentation}
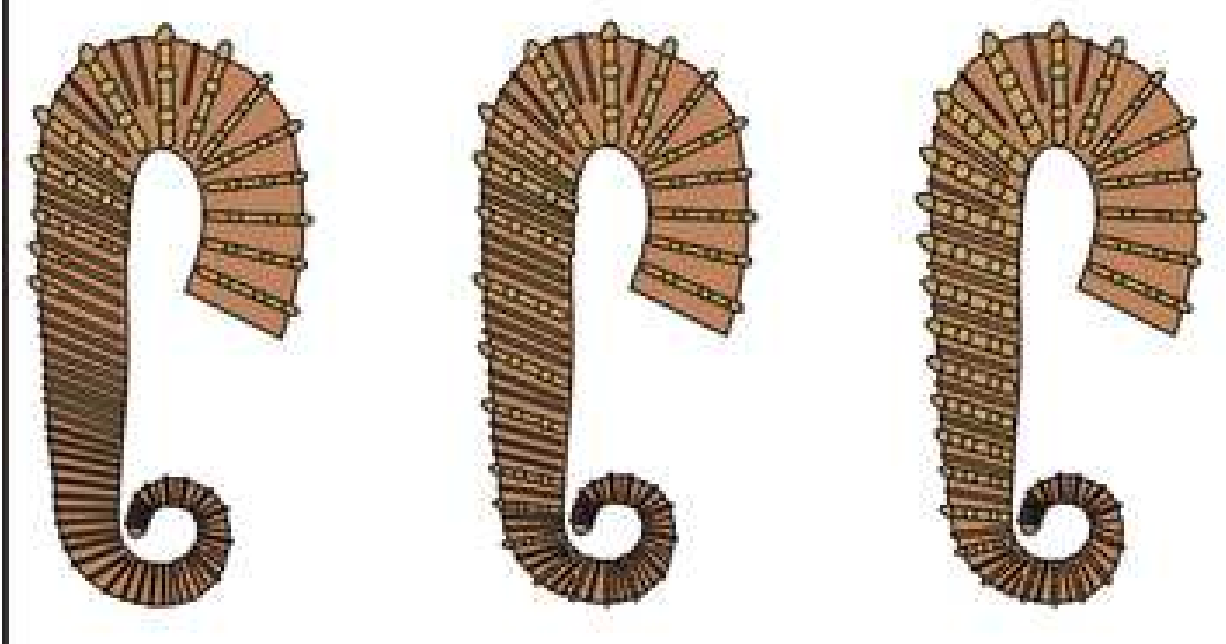

\section{Coiling}
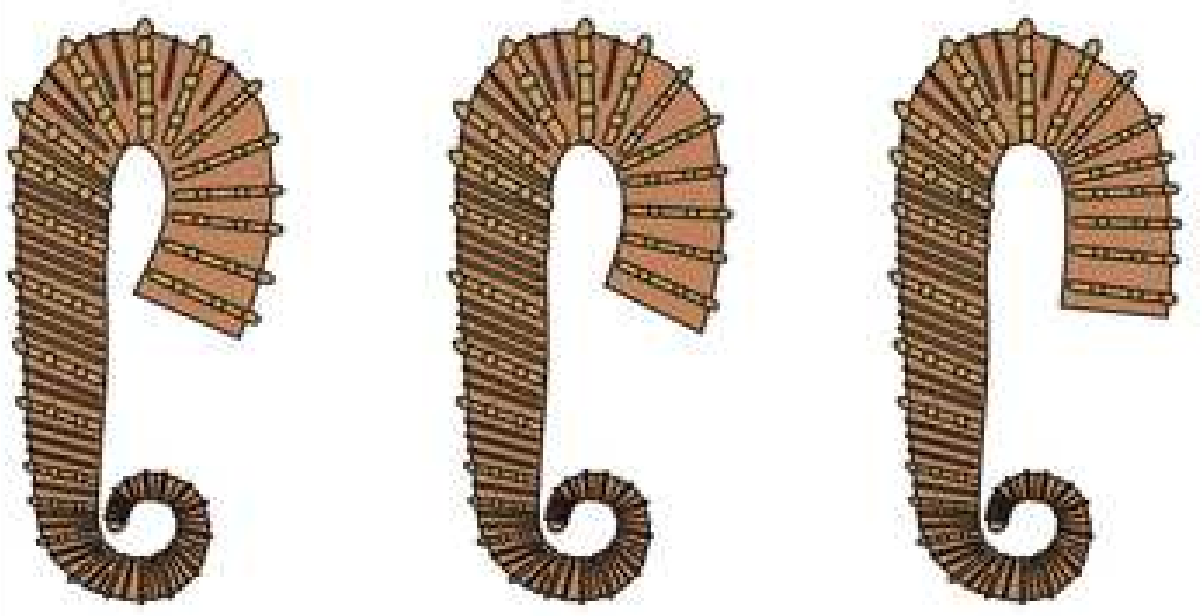


\begin{tabular}{|c|c|c|c|c|c|}
\hline & & H & $\mathbf{W}$ & $\mathbf{R}$ & $\mathbf{W} / \mathbf{H}$ \\
\hline \multirow{5}{*}{ 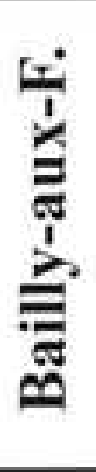 } & $\mathbf{N}$ & 2 & 2 & 2 & 2 \\
\hline & Min. & 30.4 & 30.1 & 2 & 1 \\
\hline & Max. & 34.7 & 38.1 & 2.65 & 1.09 \\
\hline & Mean & 32.55 & 34.1 & 2.31 & 1.04 \\
\hline & Var. & 9.24 & 32 & 0.19 & 0 \\
\hline \multirow{5}{*}{ 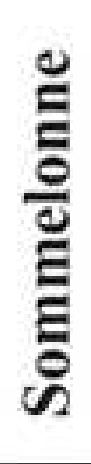 } & $\mathbf{N}$ & 4 & 3 & 4 & 3 \\
\hline & Min. & 40.1 & 41.1 & 1 & 0.9 \\
\hline & Max. & 47.6 & 49.8 & 1.86 & 1.14 \\
\hline & Mean & 44.27 & 45.66 & 1.32 & 1.03 \\
\hline & Var. & 9.94 & 19.06 & 0.13 & 0.01 \\
\hline \multirow{5}{*}{ 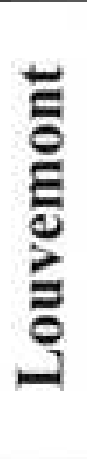 } & $\mathbf{N}$ & 11 & 11 & 9 & 11 \\
\hline & Min. & 33 & 33 & 1 & 0.86 \\
\hline & Max. & 56 & 54.2 & 8 & 1.11 \\
\hline & Mean & 43.59 & 43.03 & 3.52 & 0.99 \\
\hline & Var. & 46.35 & 37.63 & 6.5 & 0 \\
\hline \multirow{5}{*}{ 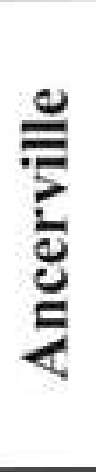 } & $\mathbf{N}$ & 2 & 2 & 1 & 2 \\
\hline & Min. & 39.7 & 46 & 2 & 1.07 \\
\hline & Max. & 54 & 58 & 2 & 1.15 \\
\hline & Mean & 46.8 & 52 & 2 & 2.23 \\
\hline & Var. & 102.2 & 72 & 0 & 0 \\
\hline \multirow{5}{*}{ 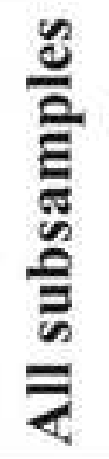 } & $\mathbf{N}$ & 19 & 18 & 16 & 18 \\
\hline & Min. & 30.4 & 30.1 & 1 & 0.86 \\
\hline & Max. & 56 & 58 & 8 & 1.15 \\
\hline & Mean & 42.92 & 43.47 & 2.72 & 1.01 \\
\hline & Var. & 47.95 & 50.36 & 4.46 & 0 \\
\hline
\end{tabular}

